\title{
Development of NIR-II Photoacoustic Probes Tailored for Deep-tissue Sensing of Nitric Oxide
}

Melissa Y. Lucero, Amanda K. East, Christopher J. Reinhardt, Adam C. Sedgwick, Shengzhang Su, Michael C. Lee, Jefferson Chan*

Department of Chemistry and Beckman Institute for Advanced Science and Technology, University of Illinois at Urbana-Champaign, Urbana, IL 61801, United States

Materials. Materials were purchased from commercial vendors and used without further purification. All deuterated solvents were purchased from Cambridge Isotope Laboratories. Acetone, dichloromethane, dimethyl sulfoxide, glacial acetic acid, phosphate saline buffer (Corning), Matrigel (Corning), Cremophor EL (Fluka), potassium phosphate dibasic, potassium phosphate monobasic, sodium bicarbonate, sodium carbonate, sodium chloride, and sodium hydroxide were purchased from Thermo Fisher Scientific. Sodium hypochlorite (14.5\% available chlorine in water) was purchased from Alfa Aesar. Agarose LE (Molecular Biology Grade) was purchased from Gold Biotechnology. Acetonitrile, anhydrous methanol, concentrated hydrochloric acid, hydrogen peroxide (30\% v/v) and sodium hydroxide were purchased from Macron Fine Chemicals. IR-1061, IR-1048, acetic anhydride, anhydrous dichloromethane, anhydrous dimethylformamide, $p$-amino-benzyl alcohol, aniline, $p$-bromo-aniline, $p$-ethyl-aniline, $p$-methyl-aniline, $p$ ethoxy-aniline, iron(II) sulfate heptahydrate, iron(III) chloride (anhydrous), copper chloride, potassium superoxide, sodium nitrite, sodium nitrate, manganese(II) chloride, $\beta$-Nicotinamide adenine dinucleotide 2'phosphate reduced tetrasodium salt hydrate (NADPH), formaldehyde (37\% w/w in water), glutathione (reduced), Mohr's salt, hexanes, L-ascorbic acid, L-NG-nitroarginine, rat liver microsomes (pooled, male), and MTT reagent were purchased from Millipore-Sigma Aldrich. IR-26 was purchased from Exciton. Potassium iodide, HEPES, $p$-anisidine, and sodium sulfate (anhydrous) were purchased from Oakwood Chemicals. Sodium a-oxyhyponitrite (Angeli's salt), DEA-NONOate and MAHMA-NONOate were purchased from Cayman Chemical. D-Luciferin were purchased from AK Scientific. A549, A549-Luc2, 4T1, and 4T1-Luc2 cells were purchased from ATCC. Cells were incubated at $37^{\circ} \mathrm{C}$ under $5 \% \mathrm{CO}_{2}$.

Instruments and Software. ${ }^{1} \mathrm{H}$ and ${ }^{13} \mathrm{C}$ NMR spectra were acquired on the Carver B500 spectrometer. The following abbreviations were used to describe coupling constants: singlet (s), doublet (d), triplet (t), or 
multiplet $(m)$. Spectra were visualized and analyzed using MestReNova (version 10.0) and referenced to trace non-deuterated solvent. High-resolution mass spectra were acquired on a Waters Q-TOF Ultima ESI mass spectrometer or a Waters Synapt G2-Si ESI/LC-MS spectrometer. Ultraviolet-visible spectroscopy was performed on a Cary 60 or Cary 5000 . Ultraviolet-visible spectroscopy and fluorimetry was performed with a micro fluorescence quartz cuvette (Science Outlet). Cells were visualized on an EVOS FL epifluorescence microscope. SpectraMax M2 plate reader was used for cell viability assays. Cell images were analyzed using Image J1. Data was analyzed using Microsoft Excel. In vivo bioluminescence imaging was performed using an IVIS Spectrum CT live-animal imaging system (Perkin-Elmer, USA). Photoacoustic imaging was performed using the MSOT InVision 128 (iTheraMedical). Reported values correspond to mean PA signals in regions of interest (ROIs) of equal area.

Statistical Analysis. Statistical analysis was performed using Microsoft Excel. For in vivo and phantom imaging, statistical analysis was performed using the Student's t-test. The $n$ value is indicated in the corresponding figure captions.
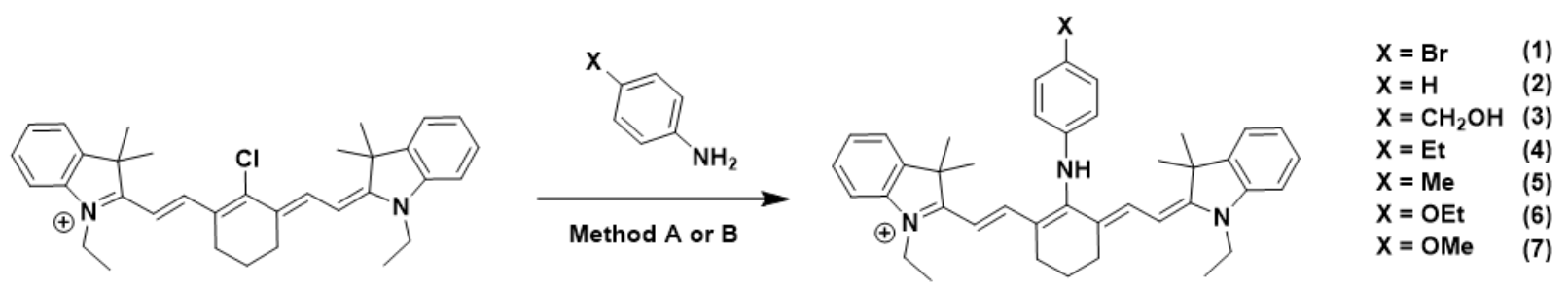

\section{Synthetic Scheme 1.}




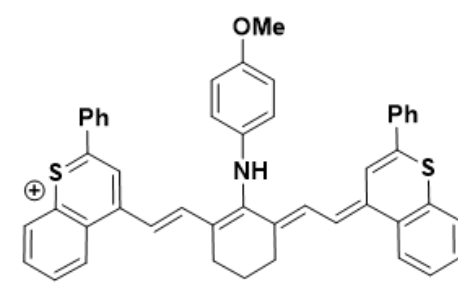

8

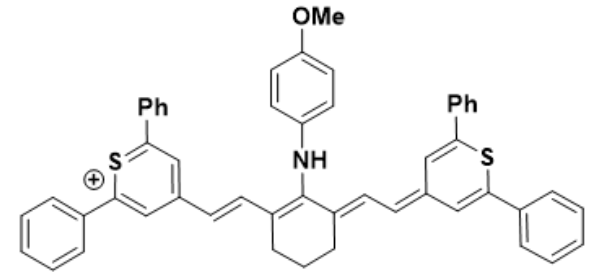

9

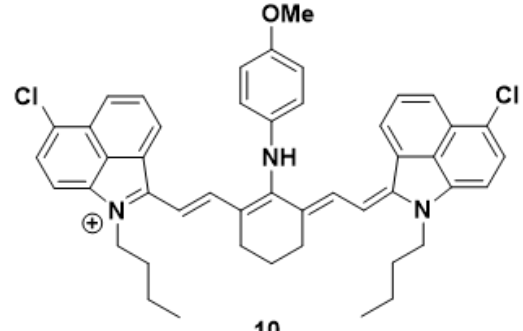

10

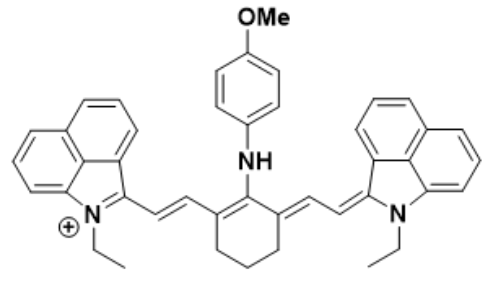

11

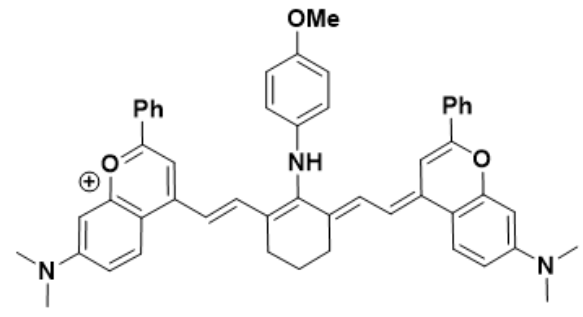

12

\section{Structures of NIR-II NO Probes.}

Photophysical Characterization. Extinction coefficients were acquired in experimental triplicate. Extinction coefficients were acquired via a known concentration of the probe within the linear range (absorbance $=0.05$ to 1.5). $50 \% \mathrm{EtOH} /$ potassium phosphate buffer $(\mathrm{pH}=7.4) . \mathrm{N}$-nitrosated products were generated by reacting probes 1-7 $(2 \mu \mathrm{M})$ with MAHMA-NONOate (100 equiv.) at $25^{\circ} \mathrm{C}$ in both $50 \mathrm{mM}$ HEPES buffer in $0.01 \% \mathrm{CrEL}(\mathrm{pH}=7.2)$ and $50 \% \mathrm{EtOH}$ potassium phosphate buffer $(\mathrm{pH}=7.4)$ for 30 minutes and 5 seconds, respectively, where complete conversion was monitored via UV-Vis spectroscopy.

Kinetics Measurements. Kinetic measurements were obtained in experimental triplicate. APNOs 1-7 (2 $\mu \mathrm{M})$ were suspended in $50 \mathrm{mM}$ HEPES buffer in $0.01 \% \mathrm{CrEL}(\mathrm{pH}=7.2)$. MAHMA-NONOate (100 equiv.) was titrated into the solution at $25^{\circ} \mathrm{C}$. UV-Vis measurements $(250-900 \mathrm{~nm})$ were taken every 30 seconds for 10 minutes, and the change in absorbance of the $\mathrm{N}$-nitrosated product was monitored. Hammet ${ }^{4}$ and pKa values were obtained and related to the experimental relative rates.

In Vitro Buffer Preparation. $20 \mathrm{mM}$ potassium phosphate solution was prepared by adding $242 \mathrm{mg}$ of $\mathrm{K}_{2} \mathrm{HPO}_{4}$ and $83 \mathrm{mg}$ of $\mathrm{KH}_{2} \mathrm{PO}_{4}$ to $100 \mathrm{~mL}$ of $\mathrm{DI}$ water. An equal volume of ethanol was added to prepare ethanolic potassium phosphate buffer. Adjustments to $\mathrm{pH}$ were made via addition of $1 \mathrm{M} \mathrm{HCl}$ or $1 \mathrm{M} \mathrm{NaOH}$. 
$\mathrm{pH}$ values were determined using a Mettler-Toledo SevenCompact $\mathrm{pH}$ meter calibrated using pH 4.0, 7.0 and 10.0 standard buffers at $25^{\circ} \mathrm{C}$.

Epifluorescence imaging of nitric oxide under AneroPack ${ }^{\circledR}$ Hypoxic Conditions. 24 well plates were seeded with $25,0004 \mathrm{~T} 1$ murine mammary carcinoma cells $(0.5 \mathrm{~mL}$ of $50,000 \mathrm{cell} / \mathrm{mL})$ in RPMI 1640 media containing $10 \%$ FBS and allowed to incubate at $37^{\circ} \mathrm{C}$ with $5 \% \mathrm{CO} 2$ for $24 \mathrm{~h}$. The media was removed, and the cells were stained with APNO-780 $(5 \mu \mathrm{M})$ in serum-free RPMI 1640 media for 90 min under the same conditions. After staining was complete, the solution was removed, and the cells were washed with PBS $(0.5-1.0 \mathrm{~mL})$ and incubated in serum-free RPMI media for $6 \mathrm{~h}$ at $37^{\circ} \mathrm{C}$ in a sealed container either with or without an AneroPack ${ }^{\circledR}$ (Mitsubishi Gas Company). When performing inhibition studies, the aforementioned solutions was prepared with L-NG-nitroarginine (L-NNA, $10 \mu \mathrm{M}$, non-selective NOS inhibitor). Each well was imaged $(n=3)$ using the Cy7 filter cube (EVOS fluorescence microscope) and analyzed using ImageJ. The average fluorescence was measured as the mean of five randomly selected cells and the error is reported between biological replicates $(n=3)$.

Selectivity Studies. The initial absorbance $(800-1200 \mathrm{~nm}$ or $500-950 \mathrm{~nm})$ was measured before the addition of reactive metals $(1 \mathrm{mM})$, thiols (GSH (1mM); Cys $\left.(500 \mu \mathrm{M}) ; \mathrm{H}_{2} \mathrm{~S}(100 \mu \mathrm{M})\right)$, oxygen $(1 \mathrm{mM})$, carbonyl $(1 \mathrm{mM})$, and nitrogen species $(1 \mathrm{mM}$; ONOO- $(50 \mu \mathrm{M})$; NO $(100 \mu \mathrm{M}))$. After addition, the reaction was sealed and incubated for $1 \mathrm{~h}$. Final measurements were recorded, and relative turn-on was determined by change in absorption at $\lambda_{\text {abs }}$ of the probe and turnover product. All metal solutions were prepared in water from their chloride salt, except for $\mathrm{FeSO}_{4} \cdot\left(\mathrm{H}_{2} \mathrm{O}\right)_{7}$. Aqueous perchlorate, nitrite, and nitrate solutions were prepared for their corresponding sodium salts. Superoxide anion was added as a solution of potassium superoxide in DMSO. Nitroxyl was generated in situ from a solution of Angeli's salt in degassed $10 \mathrm{mM}$ potassium hydroxide solution. NO was generated in situ from a solution of MAHMA-NONOate in degassed $10 \mathrm{mM}$ potassium hydroxide. Hydroxyl radical was generated via Fenton chemistry between Mohr's salt (solution in degassed $1 \mathrm{M}$ aqueous hydrochloric acid) and hydrogen peroxide. Peroxynitrite was synthesized according to a literature report ${ }^{5}$. All other analytes were prepared by dilution from commercially available sources. 
Microsome Assay. The initial absorbance of $10 \mu \mathrm{M}$ APNO-1080 with $10 \mu \mathrm{L}$ rat liver microsomes in $0.1 \mathrm{M}$ potassium phosphate buffer ( $\mathrm{pH}$ 7.4) was measured. After addition of $50 \mu \mathrm{M} N A D P H$, the reaction was incubated at $37^{\circ} \mathrm{C}$ for $1 \mathrm{~h}$. The final absorbance was measured after quenching with acetonitrile.

Cytotoxicity Assay. A549 cells were plated ( $5 \times 10^{4}$ cells/well) in a 24-well plate in Ham's F12-K (10\% FBS) media for $24 \mathrm{~h}$. A549 cells were then incubated with 0.0, 0.1, 5.0, 10.0, and $25 \mu \mathrm{M}$ APNO- 1080 at $37^{\circ} \mathrm{C}$ in serum-free DMEM media. After $24 \mathrm{~h}$, media was replaced with $5 \mathrm{mg} / \mathrm{mL}$ MTT reagent (1:20 in PBS), and incubated for $1 \mathrm{~h}$ at $37^{\circ} \mathrm{C}$. Cells were then lysed using $500 \mu \mathrm{L}$ DMSO, transferred to a 96-well plate and absorbances were measured using a plate reader at $555 \mathrm{~nm}$. Viability was measured relative to absorbance of control wells.

Tissue Phantom Preparation. Tissue phantoms were prepared by suspending agarose LE (750 mg) in deionized water $(50 \mathrm{~mL})$. The suspension was heated for 1 minute in a microwave until a viscous, translucent gel was produced. Immediately, $1 \mathrm{~mL}$ of $2 \%$ milk was added. The hot gel was poured into a mold $(0.5,1$, and $3 \mathrm{~cm}$ in depth) containing two plastic straws ( $3 \mathrm{~mm}$ diameter) and cooled at room temperature for at least 20 minutes. After cooling, the straws were removed and the gel was removed from the mold, yielding a tissue phantom with two parallel channels for the placement of FEP tubes containing sample solutions.

Tissue Phantom PA Imaging. A solution of APNO-1080 (50 $\mu \mathrm{M}$, ethanolic potassium phosphate, $\mathrm{pH} 7.4)$ with or without $100 \mu \mathrm{M}$ MAHMA-NONOate was injected into a tube which was then inserted into the cylindrical tissue phantom for imaging. The phantom was placed into the holder and excited from $700-$ $1150 \mathrm{~nm}$ with $5 \mathrm{~nm}$ intervals. The spectrum that was obtained was later used for spectral unmixing.

In the head-to-head phantom study to evaluate PA signal in varying tissue phantom depths with APNO1080 and APNO-780, $10 \mu \mathrm{M}$ in ethanolic potassium phosphate buffer (pH 7.4) with or without $100 \mu \mathrm{M}$ MAHMA-NONOate was used. 
Photostability Assay. A solution of APNO-1080 (50 $\mu \mathrm{M}$, ethanolic potassium phosphate, $\mathrm{pH}$ 7.4) was injected into a tube which was then inserted into the cylindrical tissue phantom for imaging. The phantom was placed into the holder and irradiated at $905 \mathrm{~nm}$ continuously for $300 \mathrm{~s}$. A solution of APNO-1080 or APNO-780 (50 $\mu \mathrm{M}$, ethanolic potassium phosphate, $\mathrm{pH}$ 7.4) containing $100 \mu \mathrm{M}$ MAHMA-NONOate was injected into a tube which was then inserted into the cylindrical tissue phantom for imaging. The phantom was placed into the holder and irradiated at 1045 or $705 \mathrm{~nm}$ continuously for $300 \mathrm{~s}$, respectively.

Live-subject Statement. All animal experiments were performed with the approval of the Institutional Animal Care and Use Committee (IACUC) of the University of Illinois at Urbana-Champaign, following the principles outlined by the American Physiological Society on research animal use.

Orthotopic Bioluminescent Breast Cancer Model. 6 to 8-week-old female BALB/c mice were inoculated with $4 \mathrm{~T} 1$-Luc cells $(100 \mu \mathrm{L}$ of $1 \times 106 \mathrm{cells} / \mathrm{mL}$ in $1: 1$ serum-free RPMI 1640 media and Matrigel) via subcutaneous injection into the mammary fat pad. Tumor volumes were measured using the caliper method and the body weight of the mice was monitored over the course of the experiment. After 30 days, the tumors had grown to a final volume of $300-400 \mathrm{~mm}^{3}$.

Heterotopic Bioluminescent Lung Cancer Animal Model. 4 to 5 -week-old female Nu/J mice were used to surgically inject cancer cells into the liver. The mice were anesthetized, and aseptic technique was followed throughout the procedure. A laparotomy was performed, then $5 \times 10^{6}$ A549-Luc2 cells (50 $\mu \mathrm{L}, 1: 1$ PBS:Matrigel) were slowly injected into the liver. 5-0 Vicryl sutures and wound clips were used to close the abdominal wall and skin, respectively. Tumor growth was monitored for up to 10 weeks via bioluminescence imaging. We acknowledge Drs. Herndon and Xu for performing these procedures.

In Vivo Bioluminescence Imaging. A fresh solution of D-Luciferin in DPBS (15 mg/mL) was prepared before imaging. Each mouse was administered $150 \mathrm{mg} \mathrm{D}$-Luciferin/kg of body weight via intraperitoneal (IP) injection. Each mouse was imaged using the IVIS Spectrum CT to monitor tumor burden in A549-Luc2 xenografts at 15 minutes post-injection. 
In Vivo PA Imaging. A549-Luc2 and 4T1-Luc tumor bearing mice were administered APNO-1080 (50 $\mu \mathrm{M}$, $100 \mu \mathrm{L}$ in saline containing 10\% DMSO) via retro-orbital injection. The mice were continuously anesthetized using isoflurane and placed in the prone position in the animal holder for imaging immediately before injection and 30 minutes post injection. The temperature of the imaging chamber was set to $36^{\circ} \mathrm{C}$ and the animal was allowed to equilibrate to the temperature for 10 minutes before imaging. Cross-sectional images were acquired either at the abdomen or lower mammary region of the mouse for either liver or mammary fat pad imaging with a step size of $0.3 \mathrm{~mm}$. The imaging position was guided by the built-in anatomy atlas in the MSOT InVision 128 and was kept consistent for all scans. The major wavelengths used were selected based on the absorbance of $N$-nitrosated APNO-1080 and endogenous absorbers $(700 \mathrm{~nm}, 730 \mathrm{~nm}, 760$ nm, 800 nm, 850 nm, 874 nm, 900 nm, 905 nm, 930 nm, 1000 nm, 1065 nm, 1079 nm, 1150 nm). 10 frames were recorded at every imaging wavelength. Subsequently, spectral unmixing was used to separate signals coming from hemoglobin and deoxyhemoglobin.

Field of View Selection. The field of view for all experiments performed on the MSOT InVision 128 imaging system (iTheraMedical) was selected by using the built-in, cross-sectional anatomy guide to correctly position the animals to image the mammary fat pad or liver. 


\begin{tabular}{|c|c|c|c|}
\hline Compound & $\lambda_{\text {abs }}(\mathrm{nm})$ & $\lambda_{\text {abs }}$ of -nitrosated product $(\mathrm{nm})$ & $\varepsilon\left(10^{4} \mathbf{M}^{-1} \mathbf{c m}^{-1}\right)$ \\
\hline 1 & 763 & 800 & ND \\
\hline 2 & 758 & 808 & ND \\
\hline 3 & 744 & 804 & ND \\
\hline 4 & 746 & 808 & ND \\
\hline 5 & 744 & 806 & ND \\
\hline 6 & 727 & 802 & 3.5 \\
\hline 7 (APNO-780) & 727 & 807 & ND \\
\hline 8 & Insoluble & Insoluble & ND \\
\hline 9 & 816 & 1078 & 9.2 \\
\hline 10 (APNO-1080) & 874 & 1080 & ND \\
\hline 11 & 878 & 1043 & ND \\
\hline 12 & 790 & No turnover & \\
\hline
\end{tabular}

Table S1. Photophysical properties in ethanolic potassium phosphate buffer. ND = Not determined 




Figure S1. Photostability assay where APNO-1080 with (red) and without (blue) NO treatment is continuously irradiated with a pulsed laser at their respective $\lambda_{\text {abs }}$ for $300 \mathrm{~s}$. Photostability assay where APNO-780 with (black) NO treatment is continuously irradiated with a pulsed laser at its respective $\lambda_{\text {abs }}$ for $300 \mathrm{~s}$. 

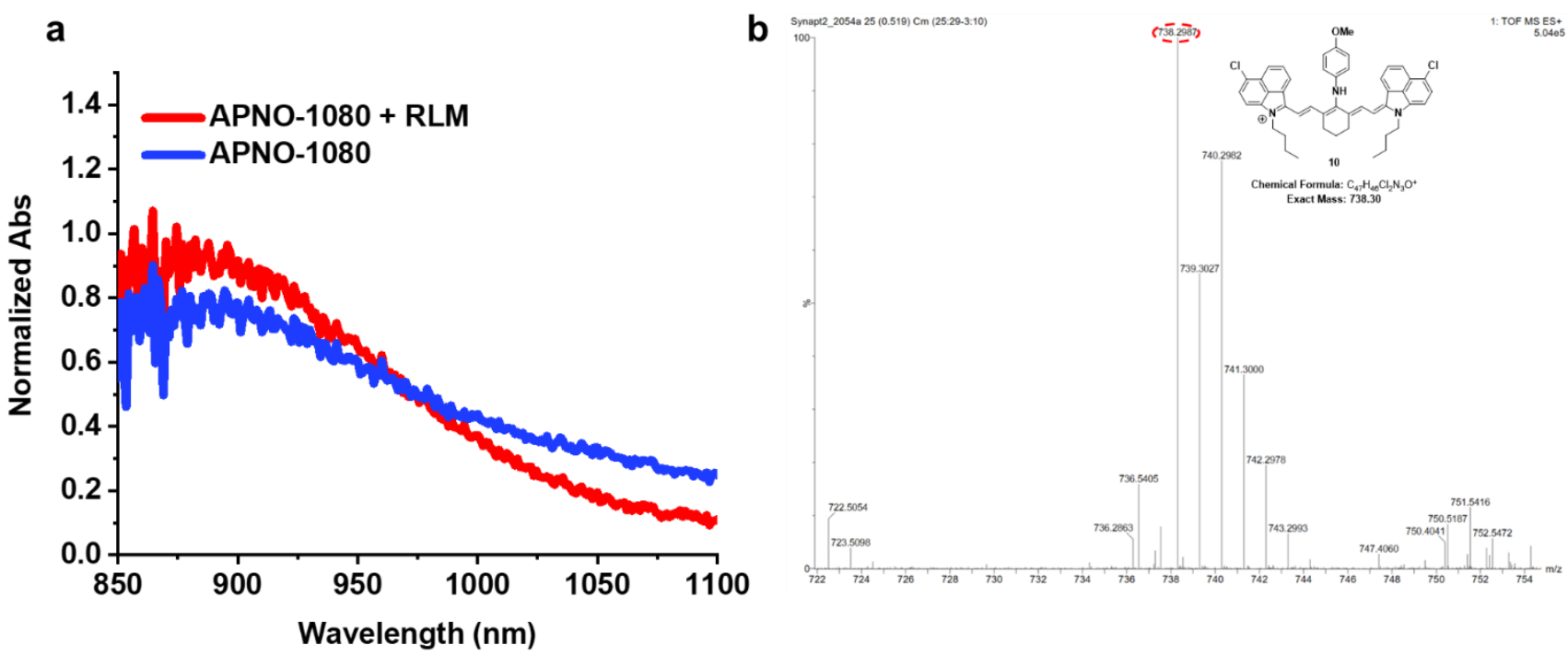

Figure S2. a) Normalized absorbance spectra of APNO-1080 after $1 \mathrm{~h}$ incubation with rat liver microsomes (red) and $1 \mathrm{~h}$ without rat liver microsomes (blue). b) ESI-MS of rat liver microsome assay shown in Figure S2a). 




Figure S3. Quantified PA imaging data of APNO-780 and APNO-1080 treated with and without NO. Solutions were overlayed with a $3 \mathrm{~cm}$ thick tissue imaging phantom. Error bars $=\operatorname{SD}(n=3)$. 


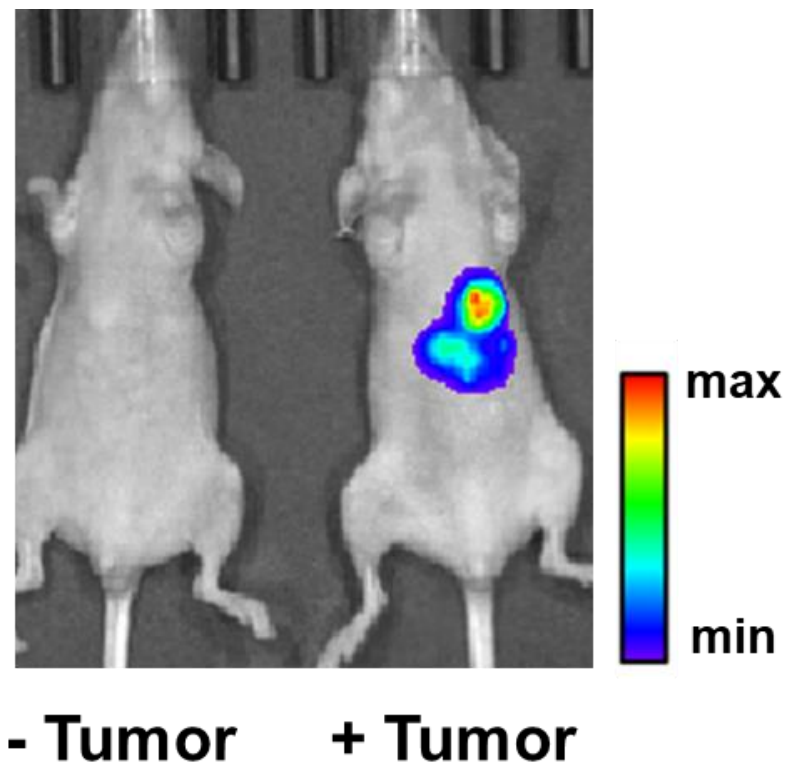

Figure S4. Representative bioluminescent images of heterotopic A549-Luc2 xenograft model of liver metastasis. 
a

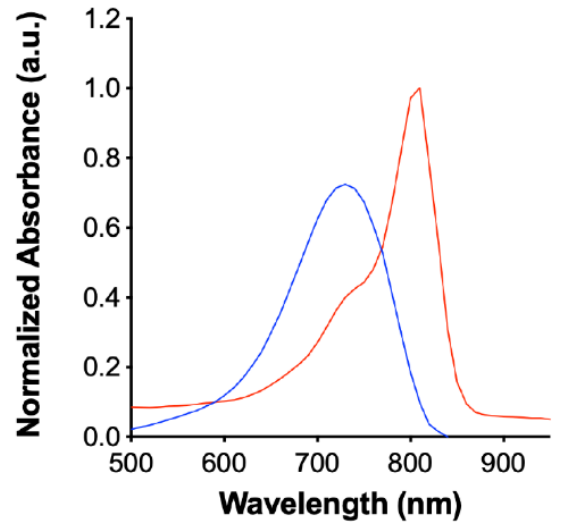

C



b

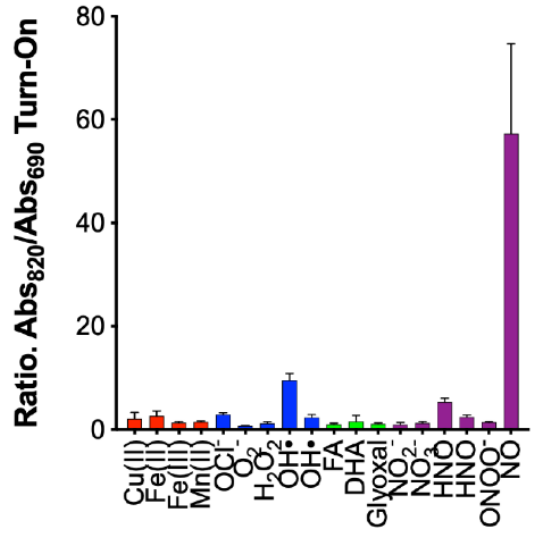

d

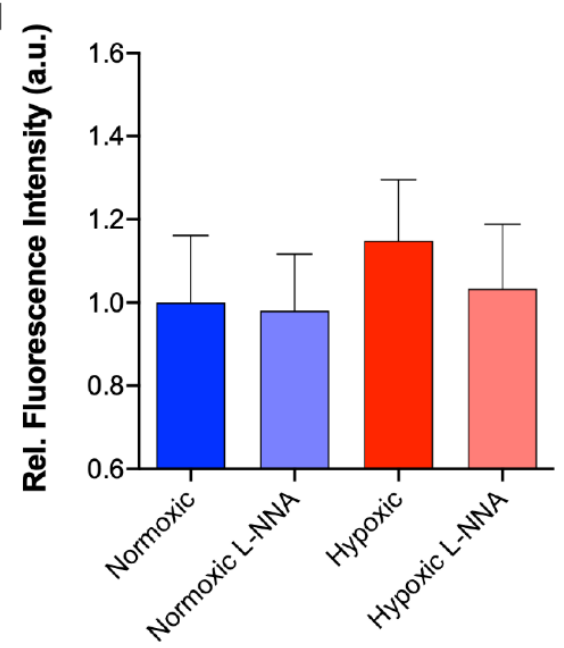

Figure S5. a) Normalized absorbance spectra of APNO-780 with (red) and without (blue) NO treatment. b) APNO-780 $(5 \mu \mathrm{M})$ absorption enhancement following $1 \mathrm{~h}$ treatment with excess (100 equiv.) reactive metal (red), carbonyl (green), oxygen (blue), or nitrogen (purple) species except for hydroxyl radical and peroxynitrite (10 equiv). c) Relative fluorescence observed following exogenous NO administration or d) endogenous hypoxic NO stimulation in 4T1 breast cancer cells. All spectra and assays were performed in $50 \mathrm{mM}$ HEPES buffer $(\mathrm{pH}=7.4)$ containing $0.1 \% \mathrm{CrEL}(\mathrm{v} / \mathrm{v})$. Relative fluorescence intensity was compared using an unpaired t-test $(\alpha=0.05) .{ }^{*}, p<0.05 ;{ }^{* *}, p<0.01$. Data presented as mean \pm standard deviation $(n=3)$ for b-c. 
a

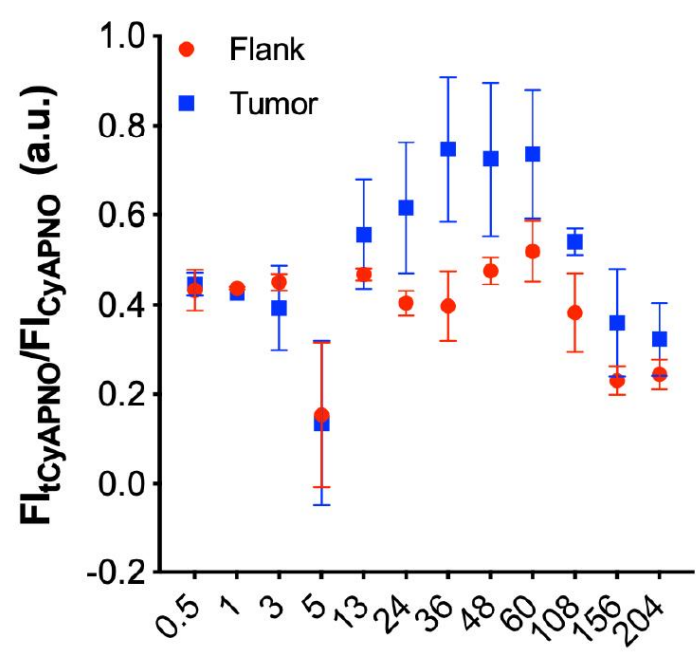

b

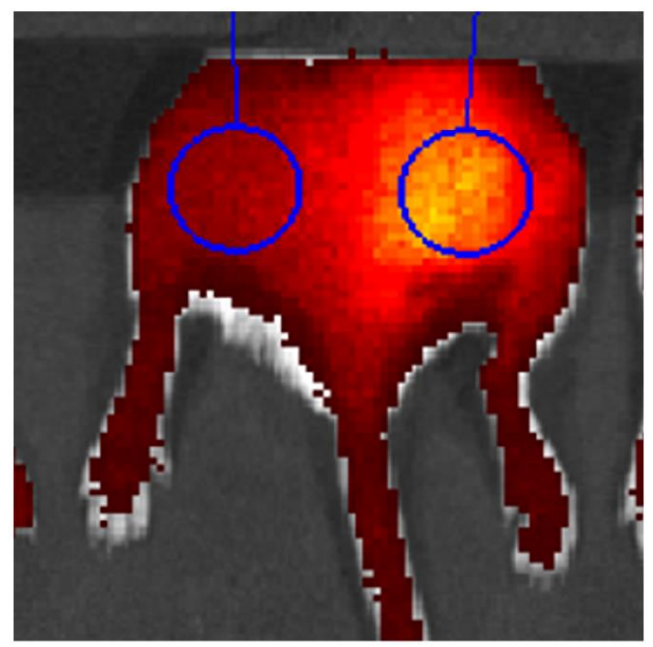

Time (h)

Figure S6. a) Ratiometric fluorescence imaging of $\mathrm{NO}$ in a heterotopic $4 \mathrm{~T} 1$ breast cancer model following systemic administration of APNO-780 (100 $\mu \mathrm{L}, 100 \mu \mathrm{M}$, retro-orbital). b) Representative image of fluorescence corresponding to the turnover product of APNO-780 in the flank (left) and tumor (right). Fluorescence intensity corresponding to APNO-780 is similar in the flank at tumor. Data presented as mean \pm standard deviation $(n=3)$. These results indicate APNO-780 is not suitable for in vivo imaging of cancer. 




Figure S7. Photostability assay where ICG $(50 \mu \mathrm{M})$ is continuously irradiated with a pulsed laser at 810 nm $300 \mathrm{~s}$. 
Compound 1: ${ }^{1} \mathrm{H}$ NMR (500 MHz, $\mathrm{CD}_{3} \mathrm{OD}$ )

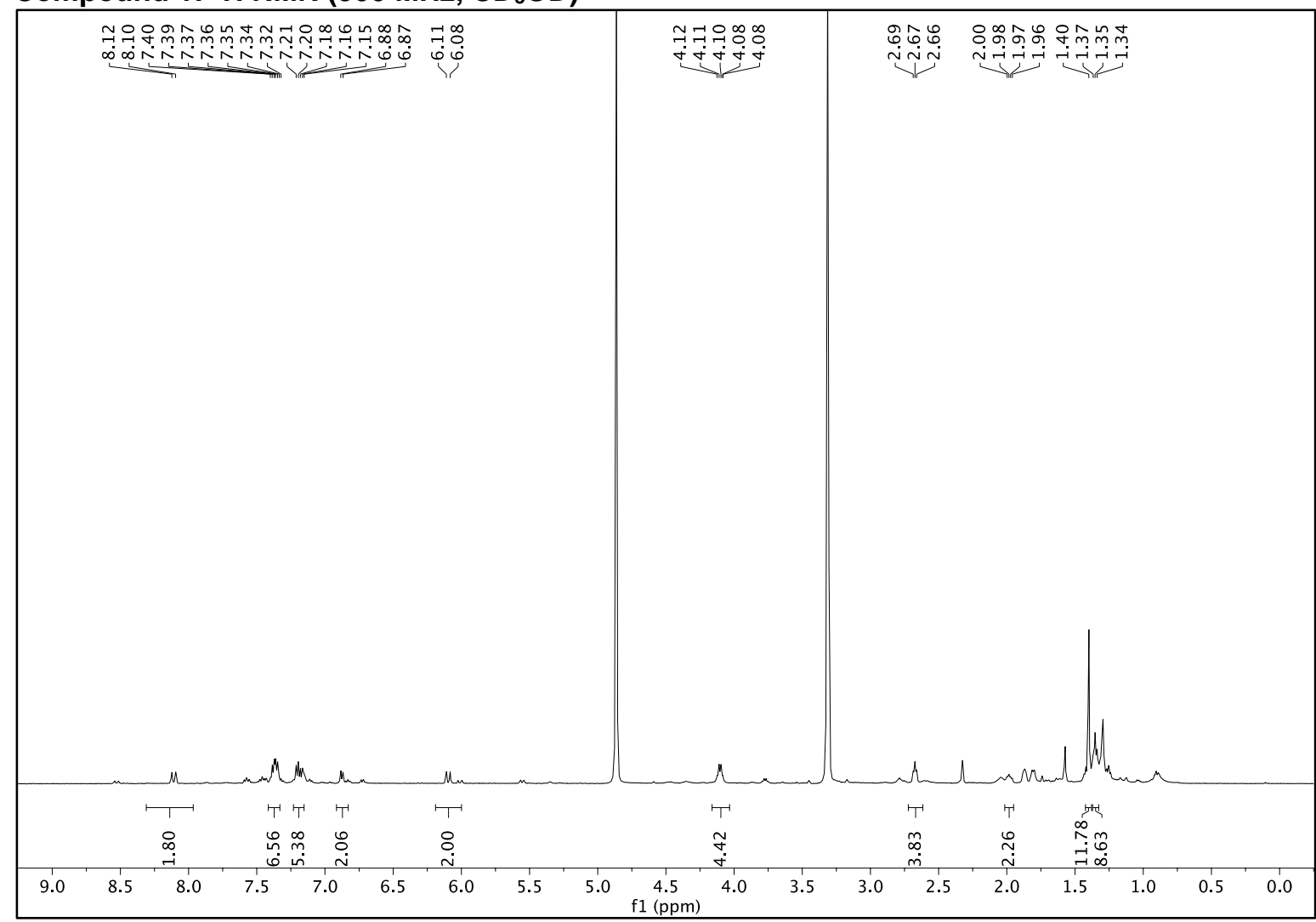

\section{Compound 1: ${ }^{13} \mathrm{C}$ NMR (125 MHz, $\mathrm{CD}_{3} \mathrm{OD}$ )}

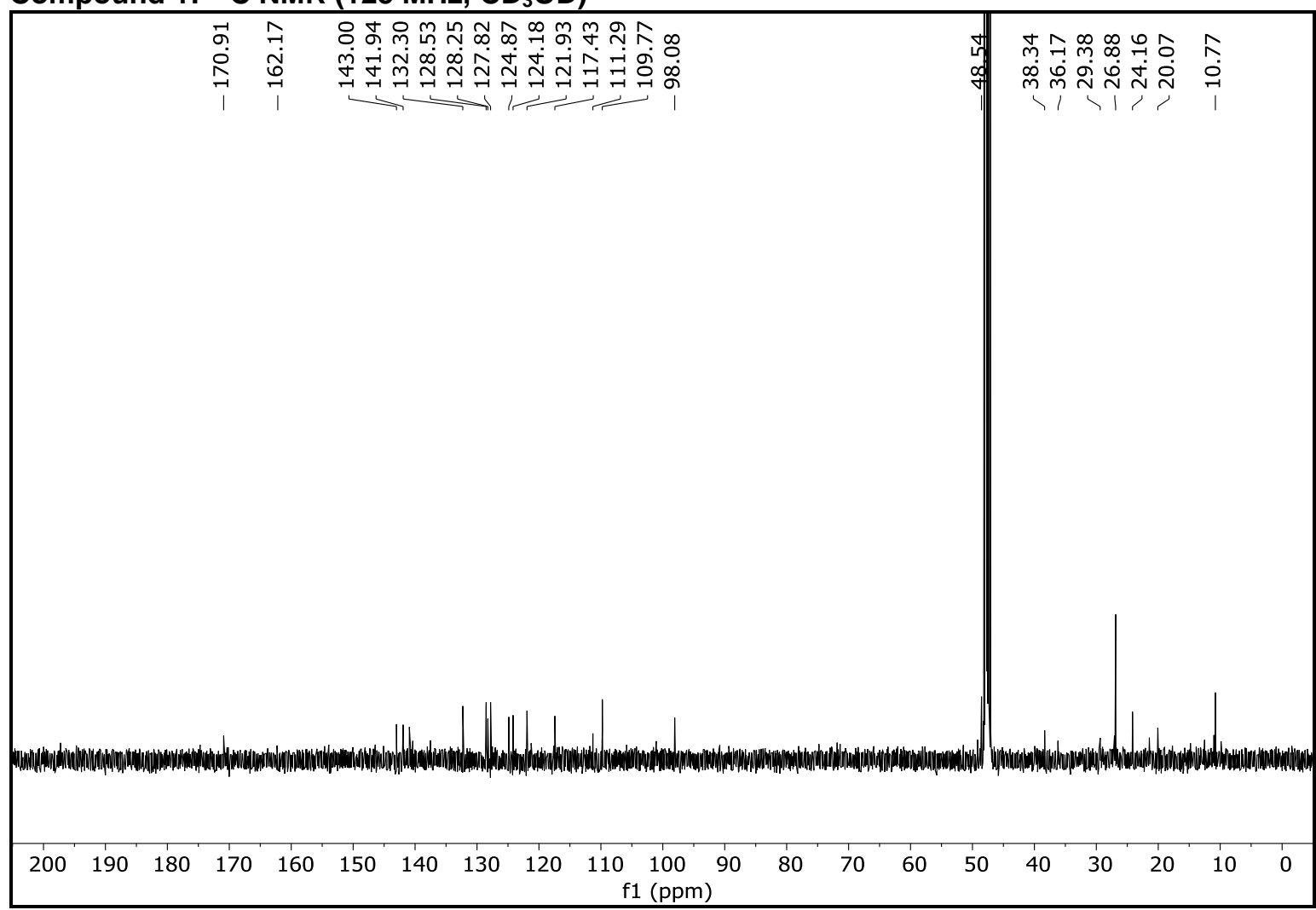




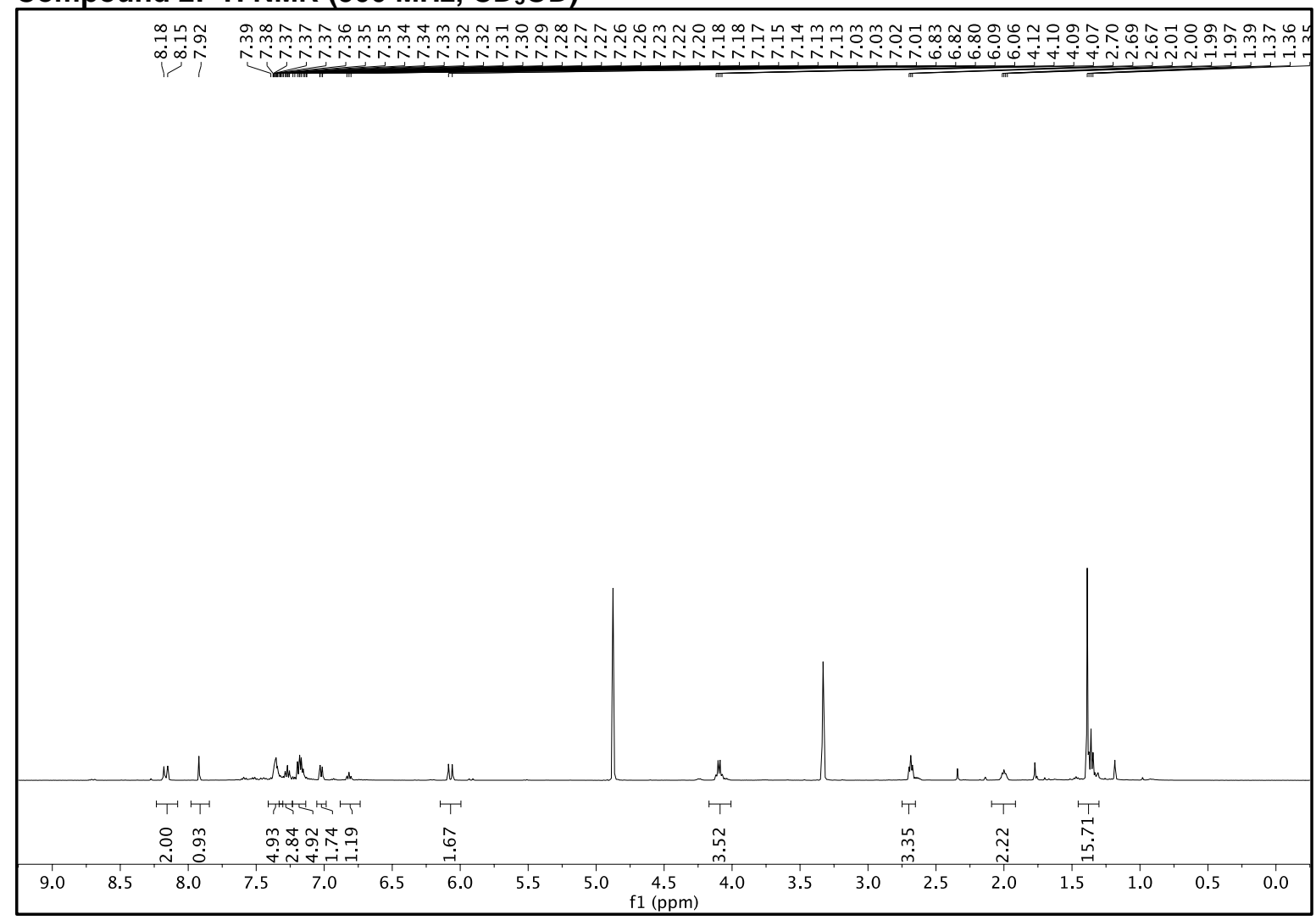

\section{Compound 2: ${ }^{13} \mathrm{C}$ NMR (125 MHz, $\mathrm{CD}_{3} \mathrm{OD}$ )}

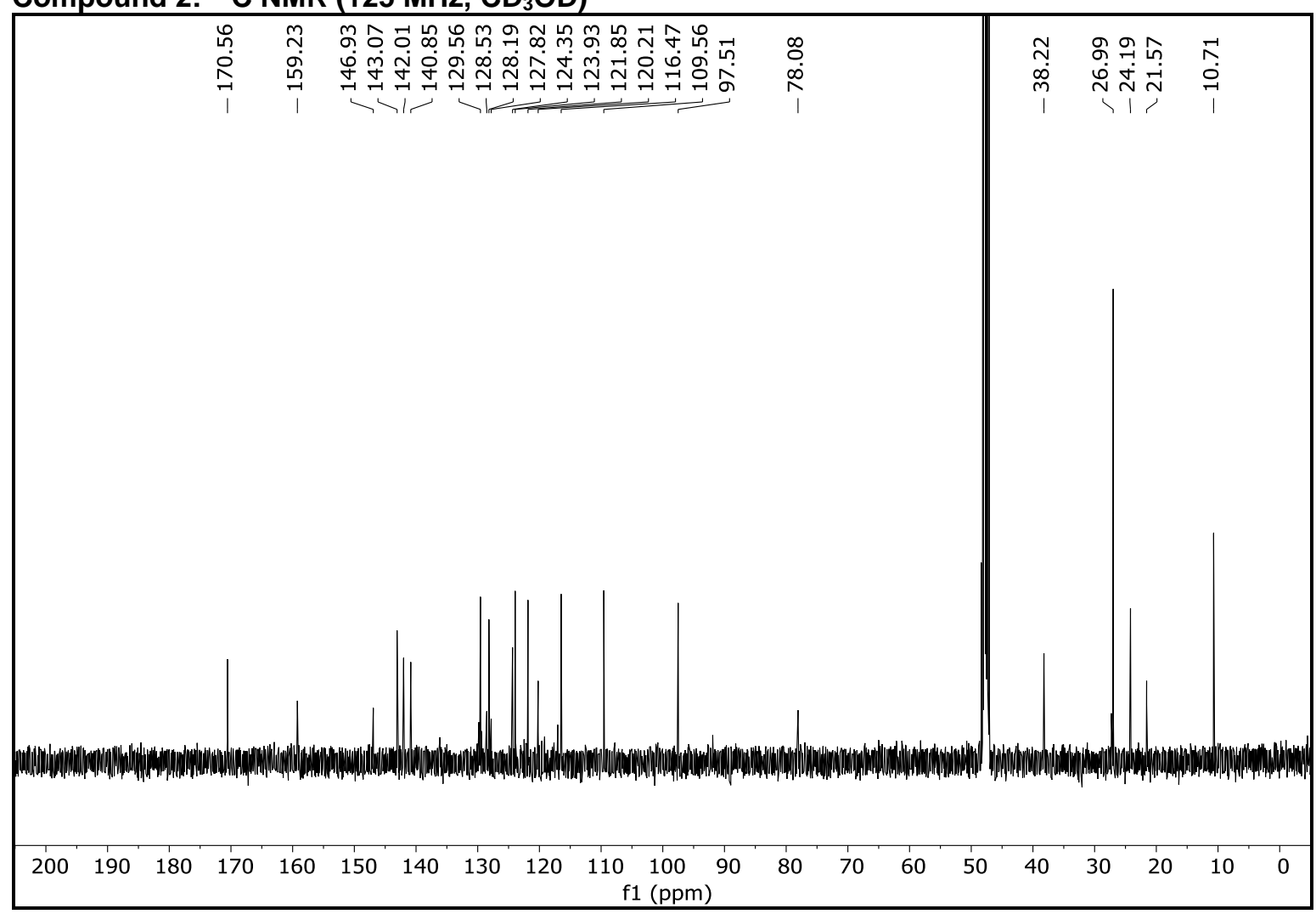


Compound 3: ${ }^{1} \mathrm{H}$ NMR (500 MHz, $\mathrm{CD}_{3} \mathrm{OD}$ )

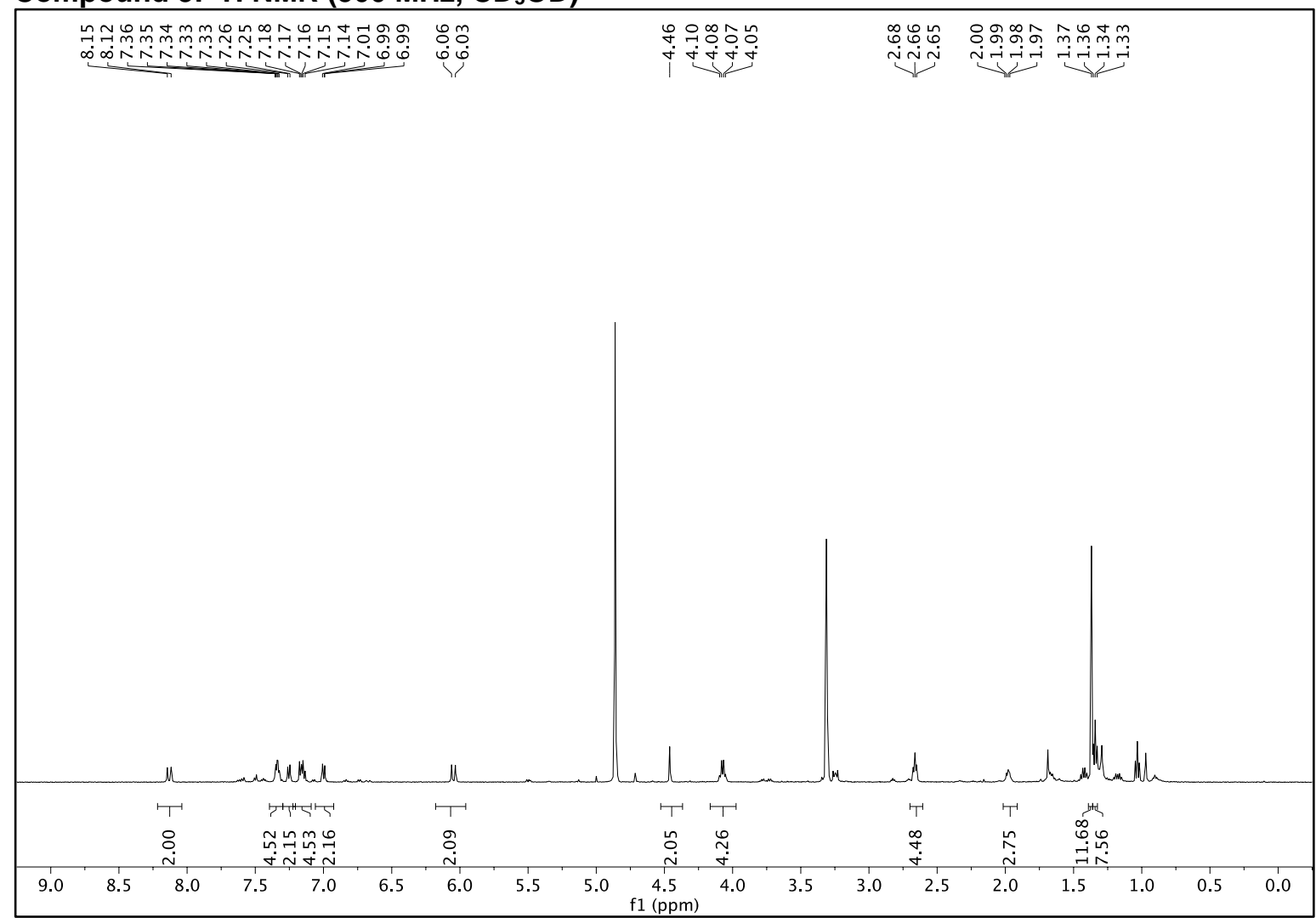

\section{Compound 3: ${ }^{13} \mathrm{C}$ NMR (125 MHz, $\mathrm{CD}_{3} \mathrm{OD}$ )}

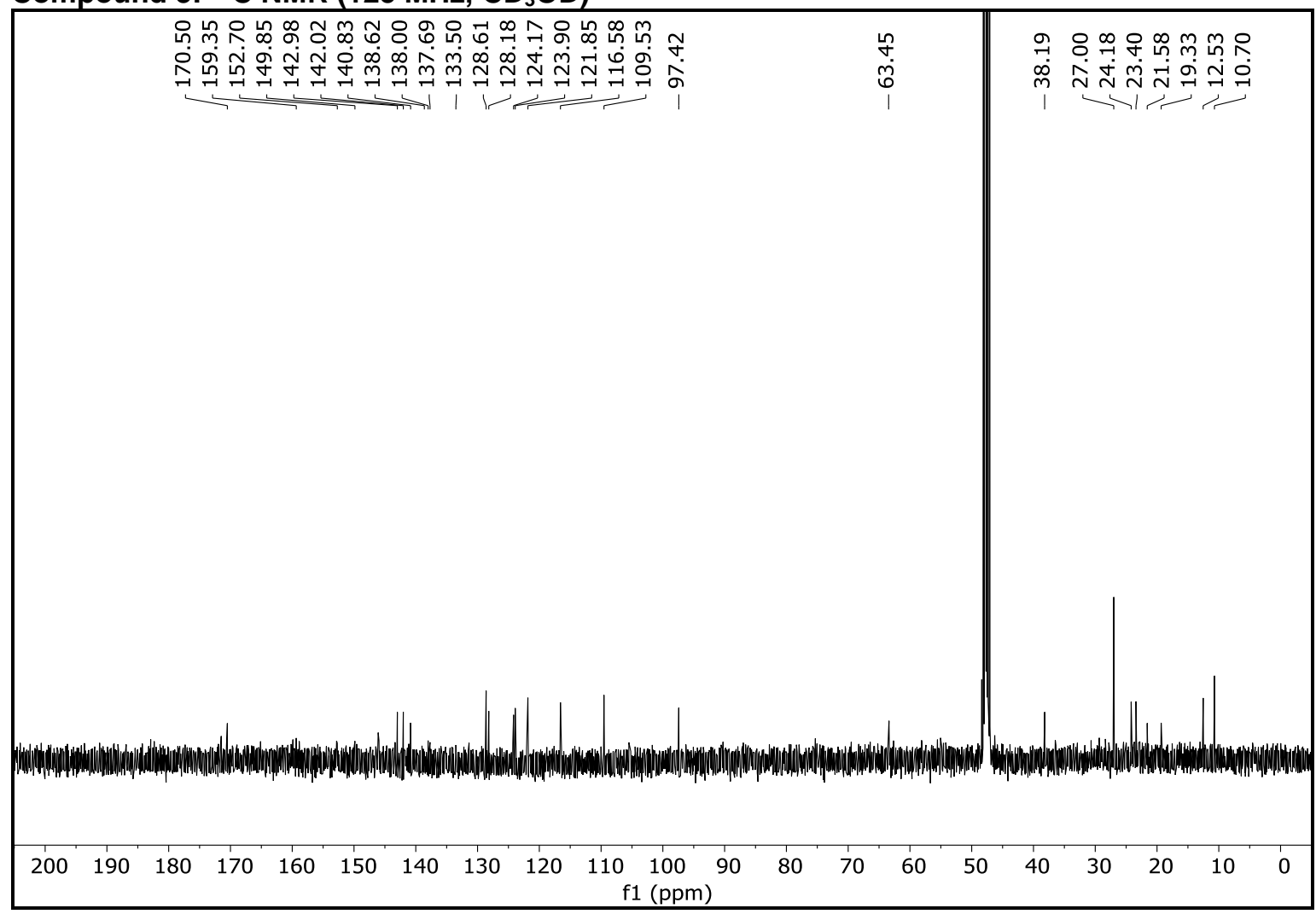




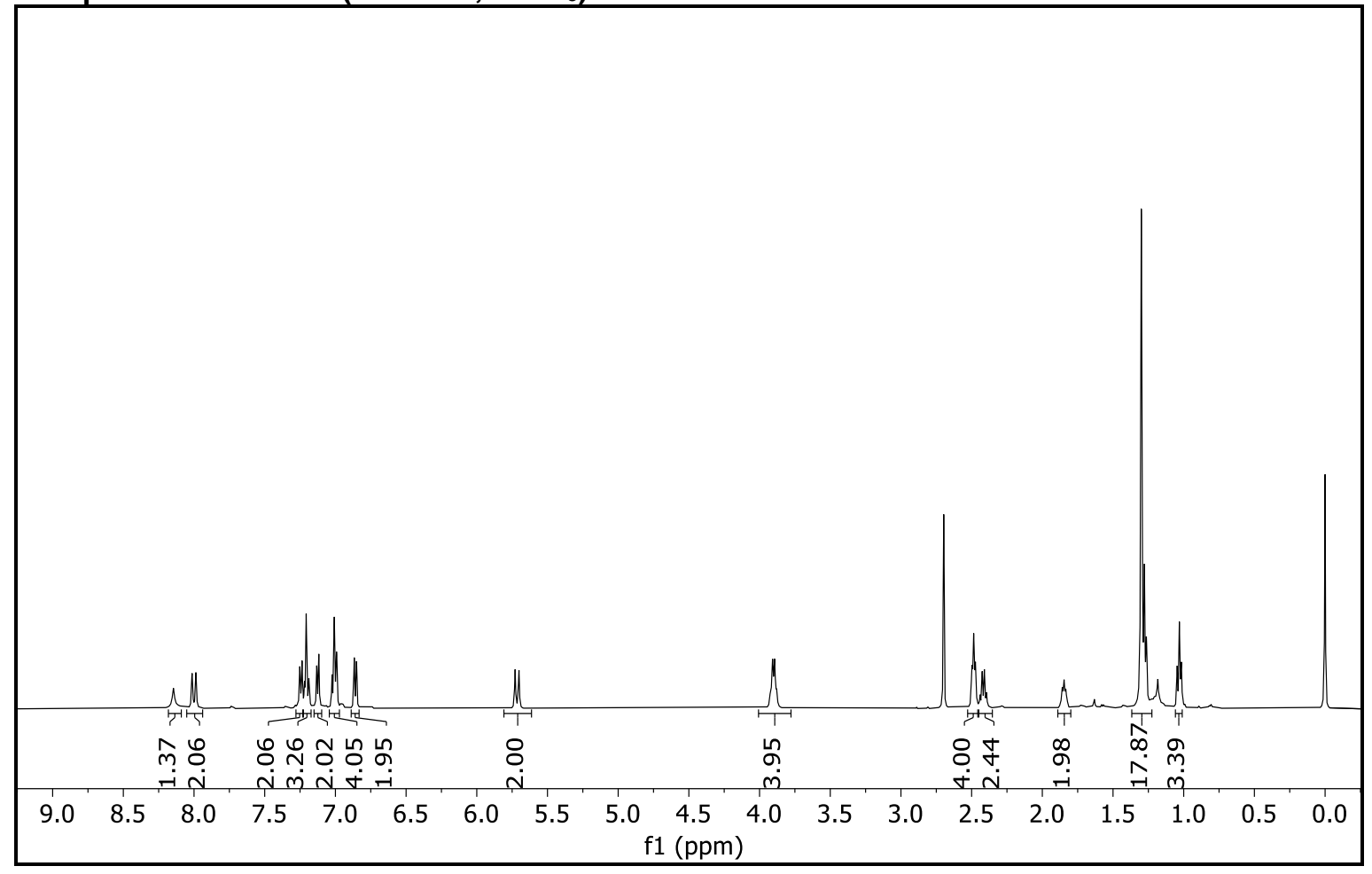

Compound 4: ${ }^{13} \mathrm{C} \mathrm{NMR} \mathrm{(125} \mathrm{MHz,} \mathrm{CDCl}_{3}$ )

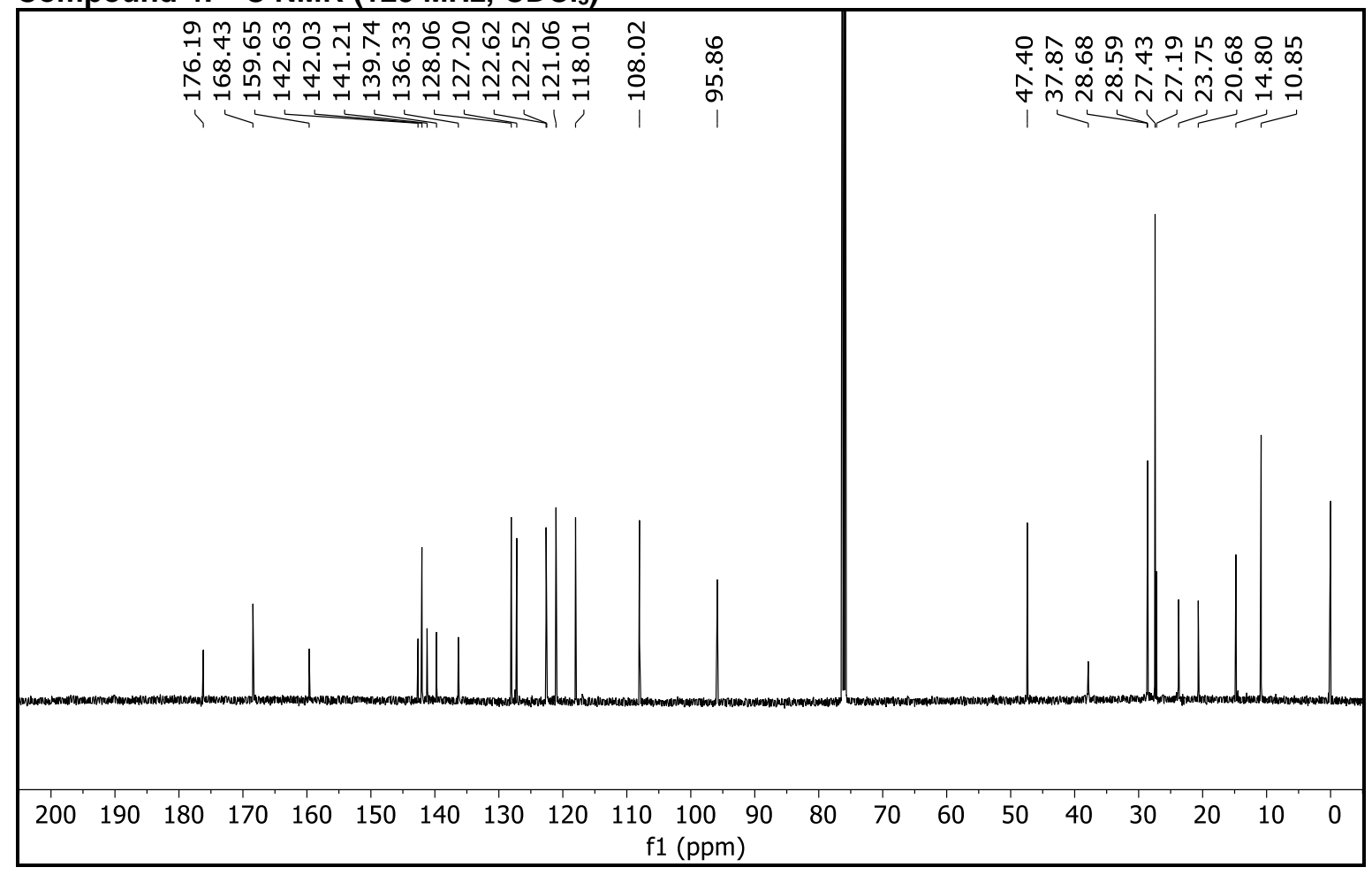


Compound 5: ${ }^{1} \mathrm{H}$ NMR (500 MHz, $\mathrm{CD}_{3} \mathrm{OD}$ )



\section{Compound 5: ${ }^{13} \mathrm{C}$ NMR (125 MHz, $\mathrm{CD}_{3} \mathrm{OD}$ )}

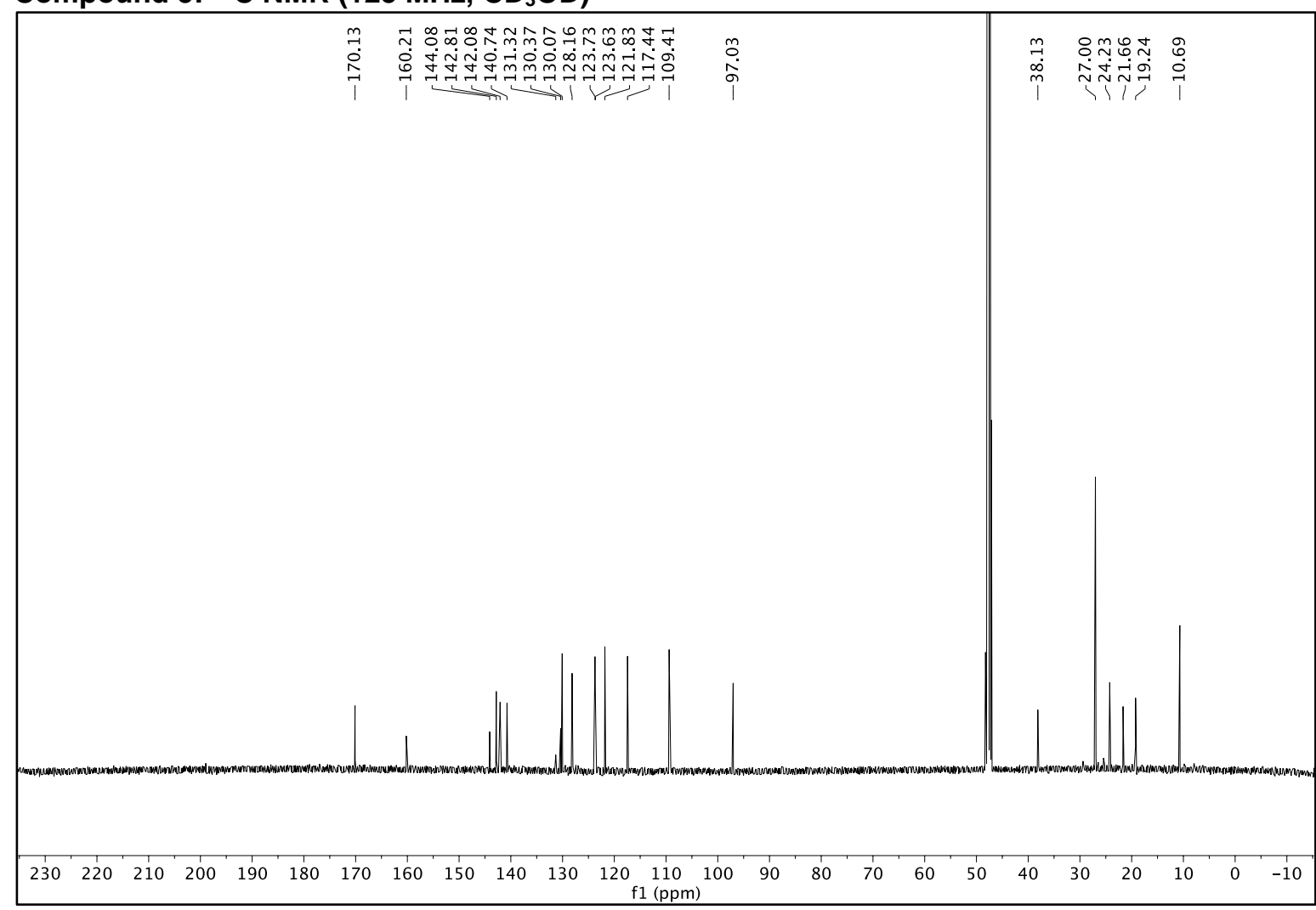




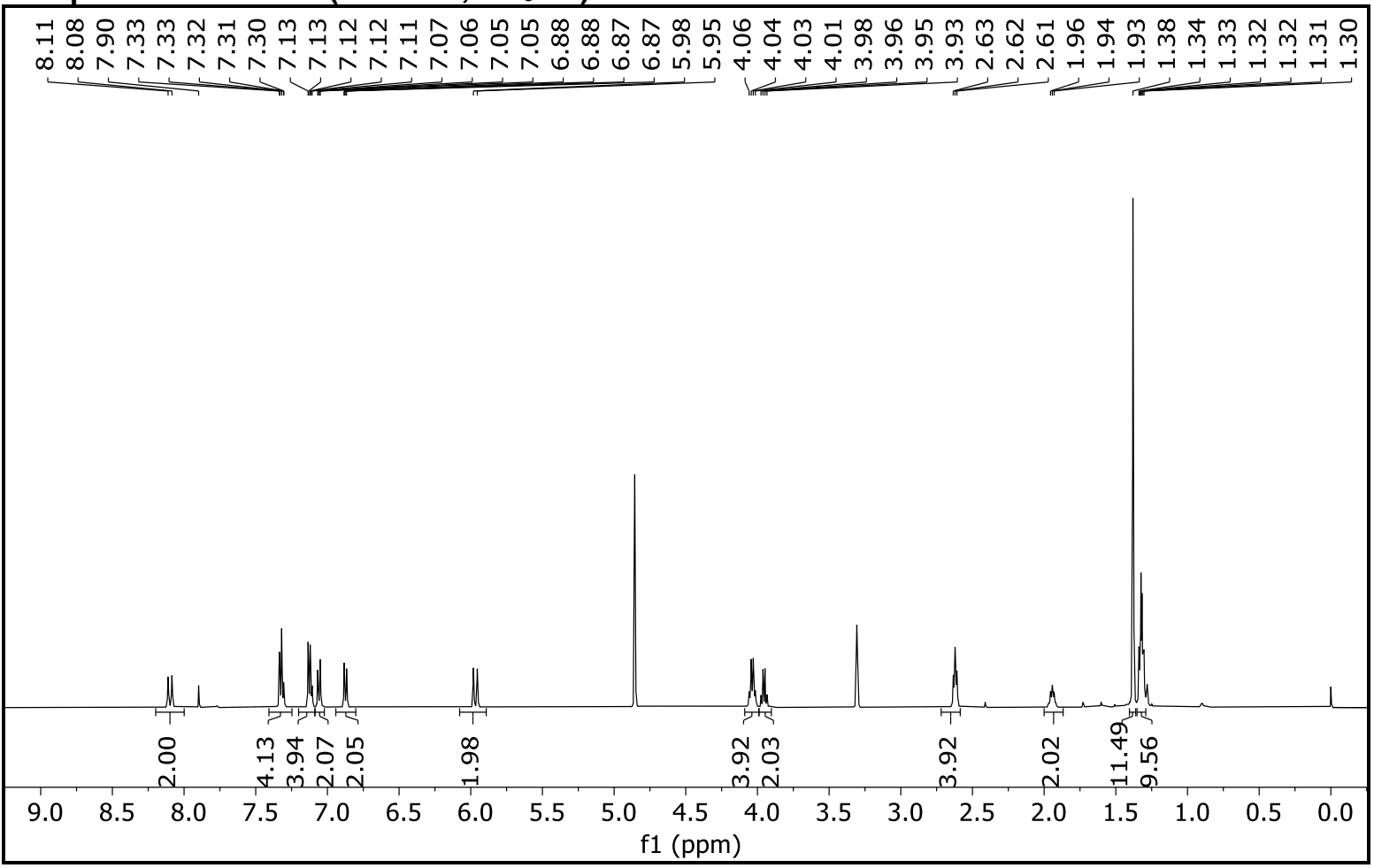

Compound 6: ${ }^{13} \mathrm{C}$ NMR (125 MHz, $\mathrm{CD}_{3} \mathrm{OD}$ )

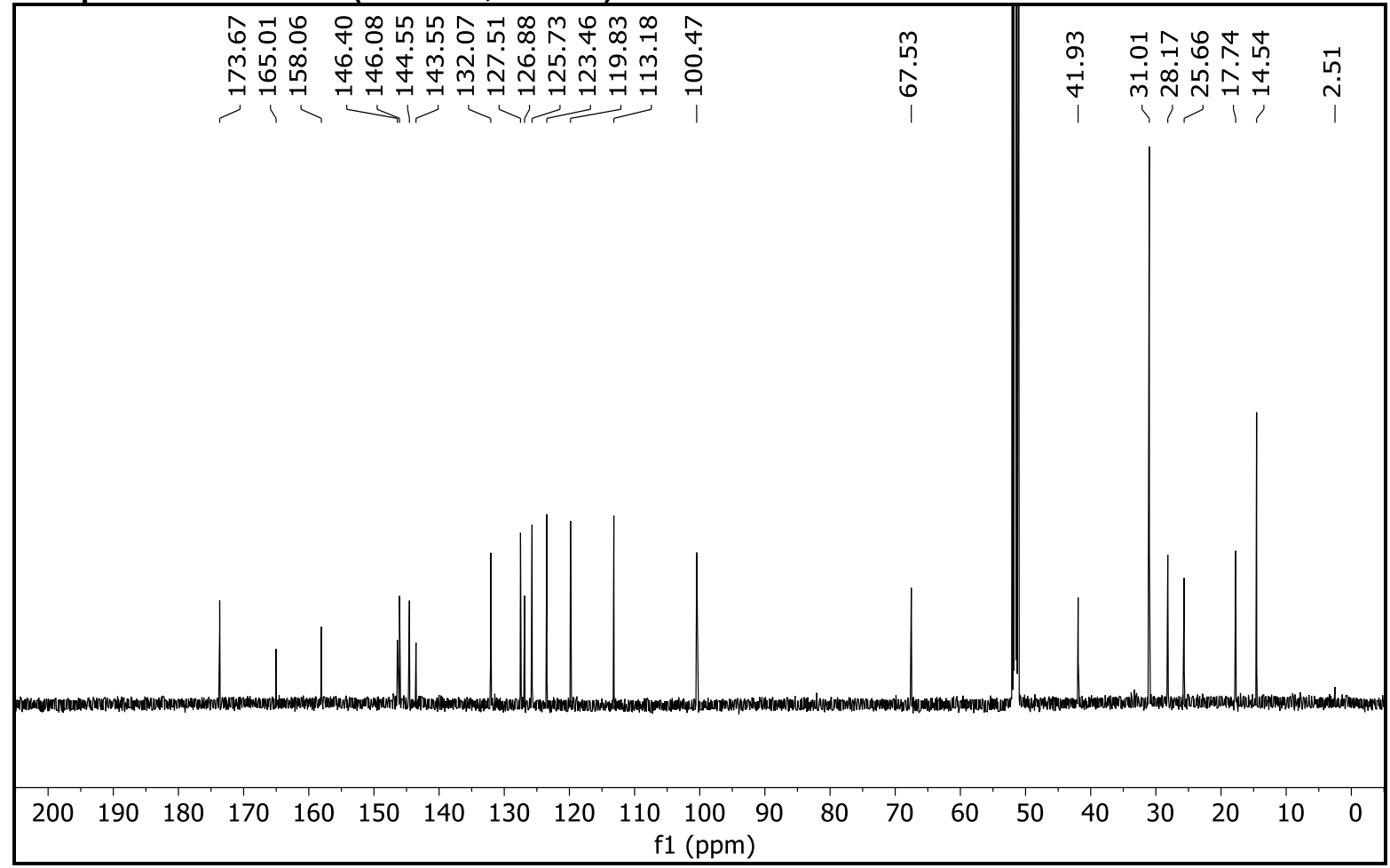


Compound 7: ${ }^{1} \mathrm{H}$ NMR (500 MHz, $\mathrm{CD}_{3} \mathrm{OD}$ )

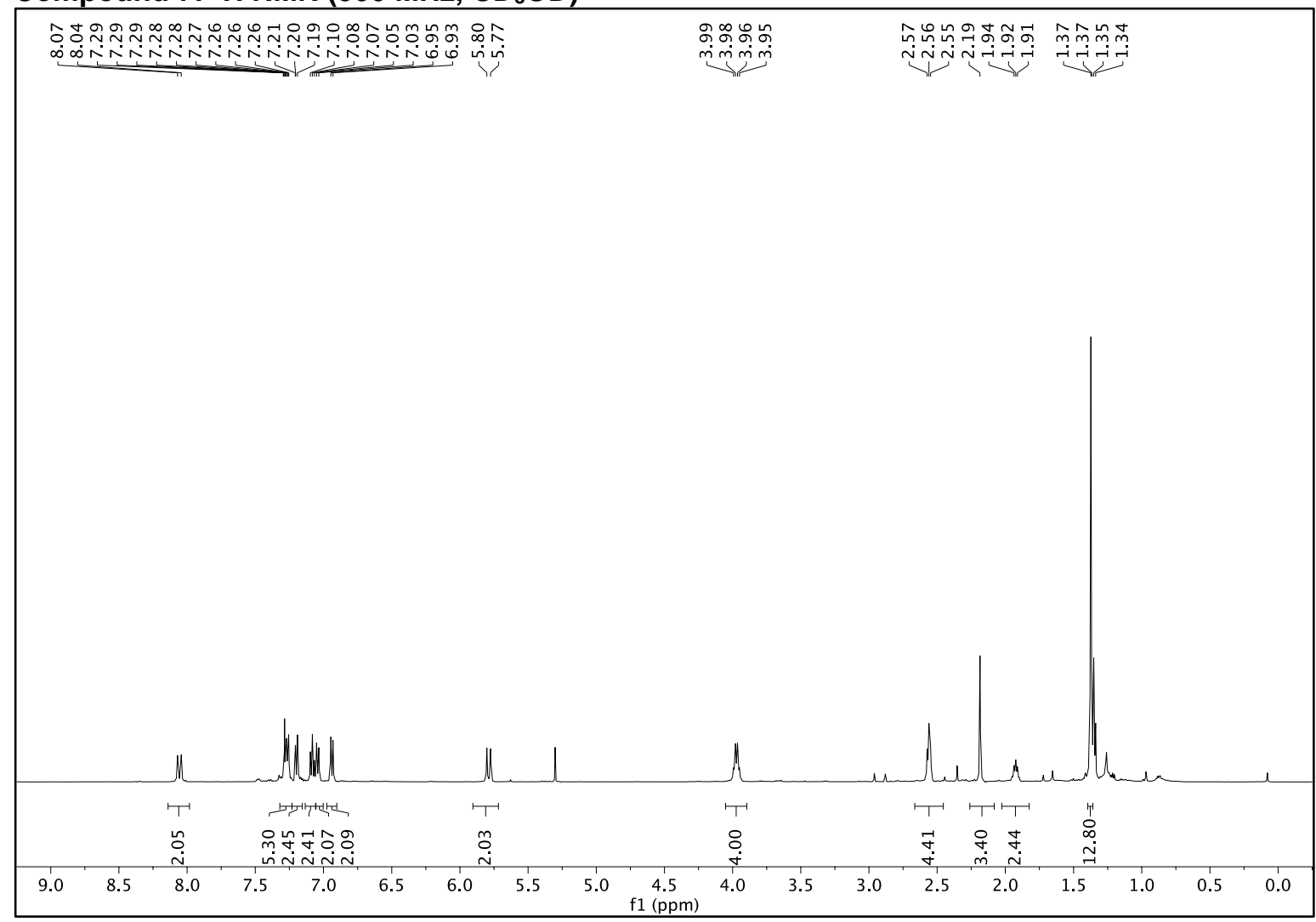

Compound 7: ${ }^{13} \mathrm{C}$ NMR (125 MHz, $\mathrm{CD}_{3} \mathrm{OD}$ )

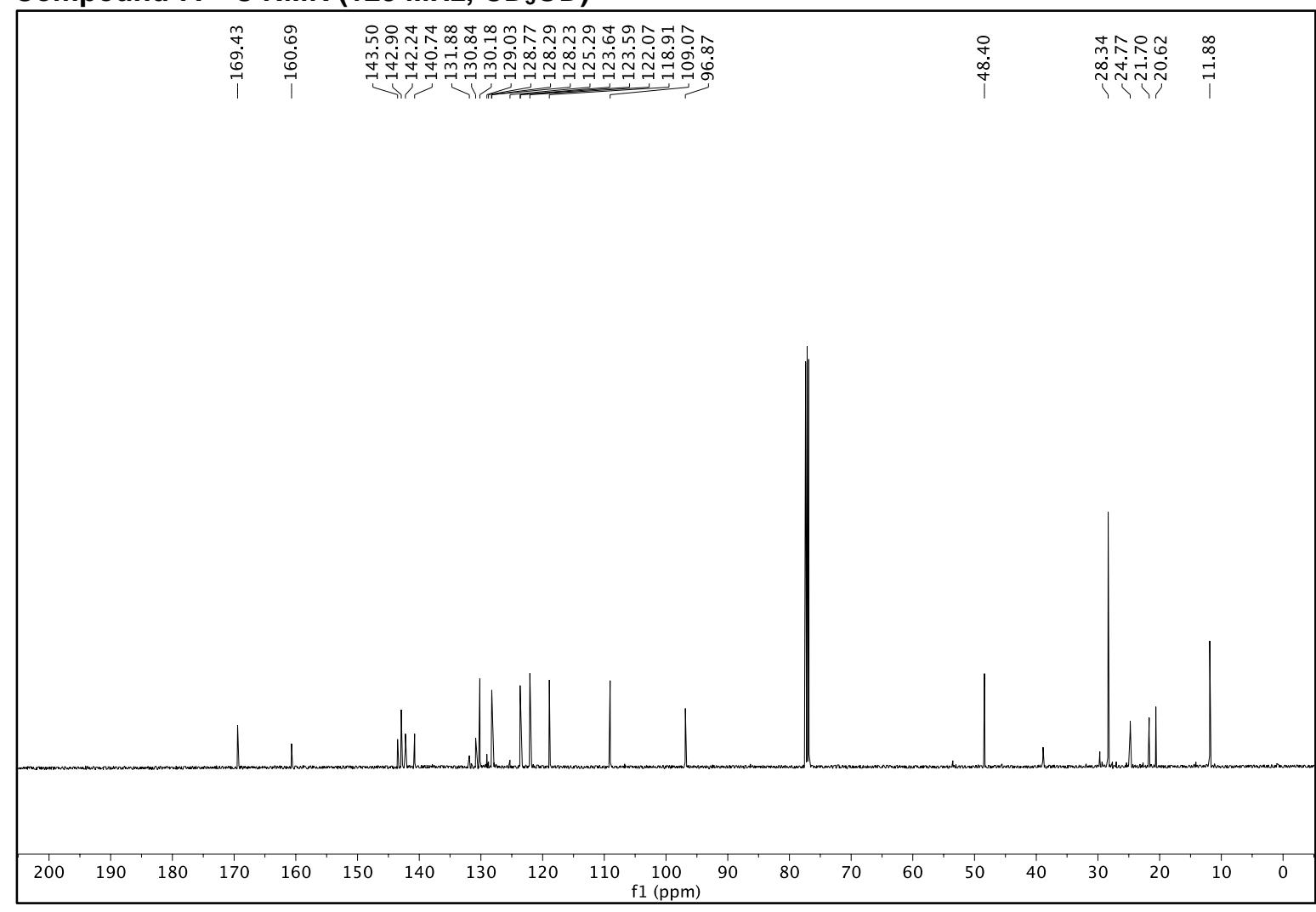


Compound 8: ${ }^{1} \mathrm{H}$ NMR (400 MHz, DMSO-d 6 )

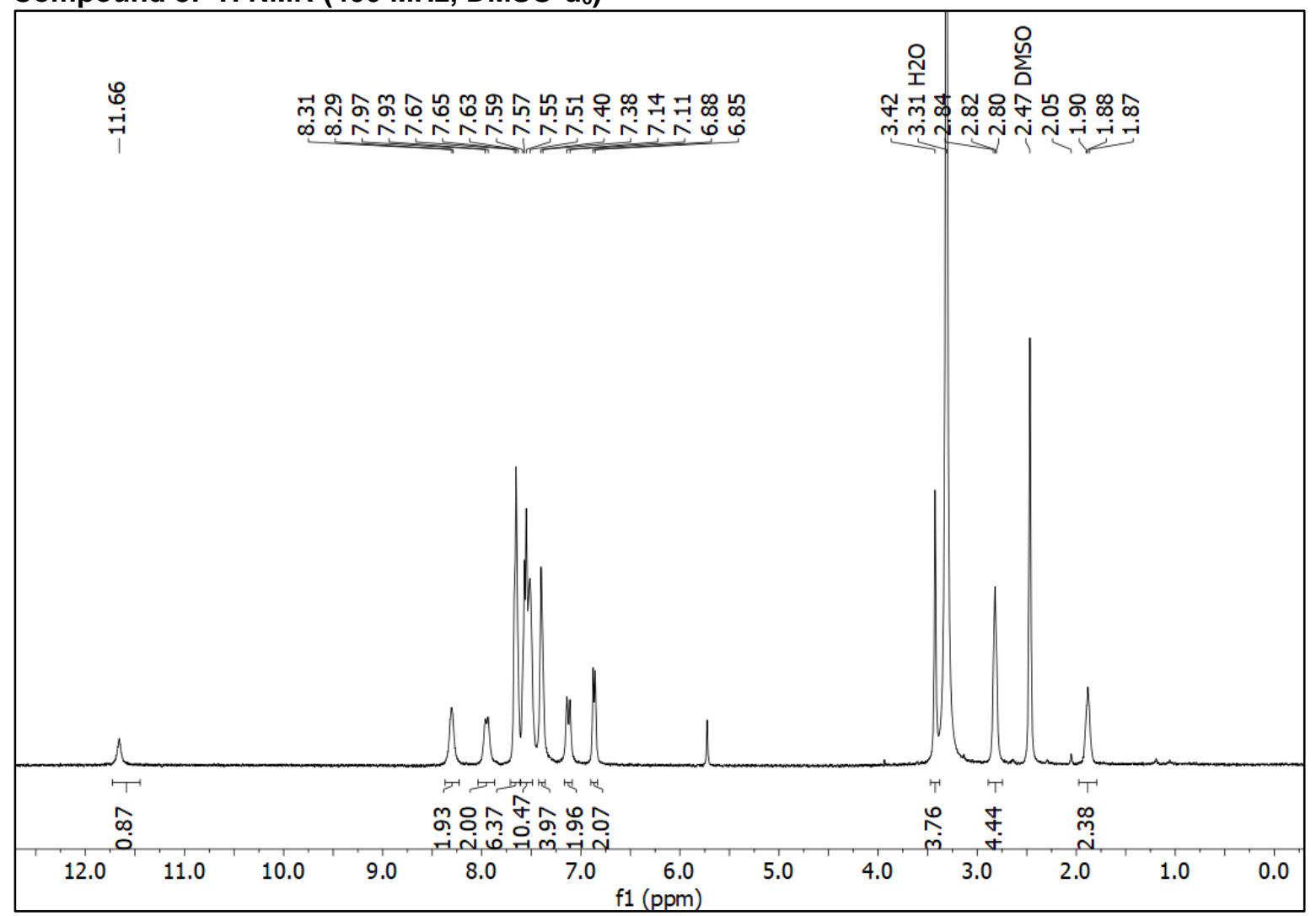


Compound 9: ${ }^{1} \mathrm{H}$ NMR (500 MHz, $\mathrm{CDCl}_{3}$ )

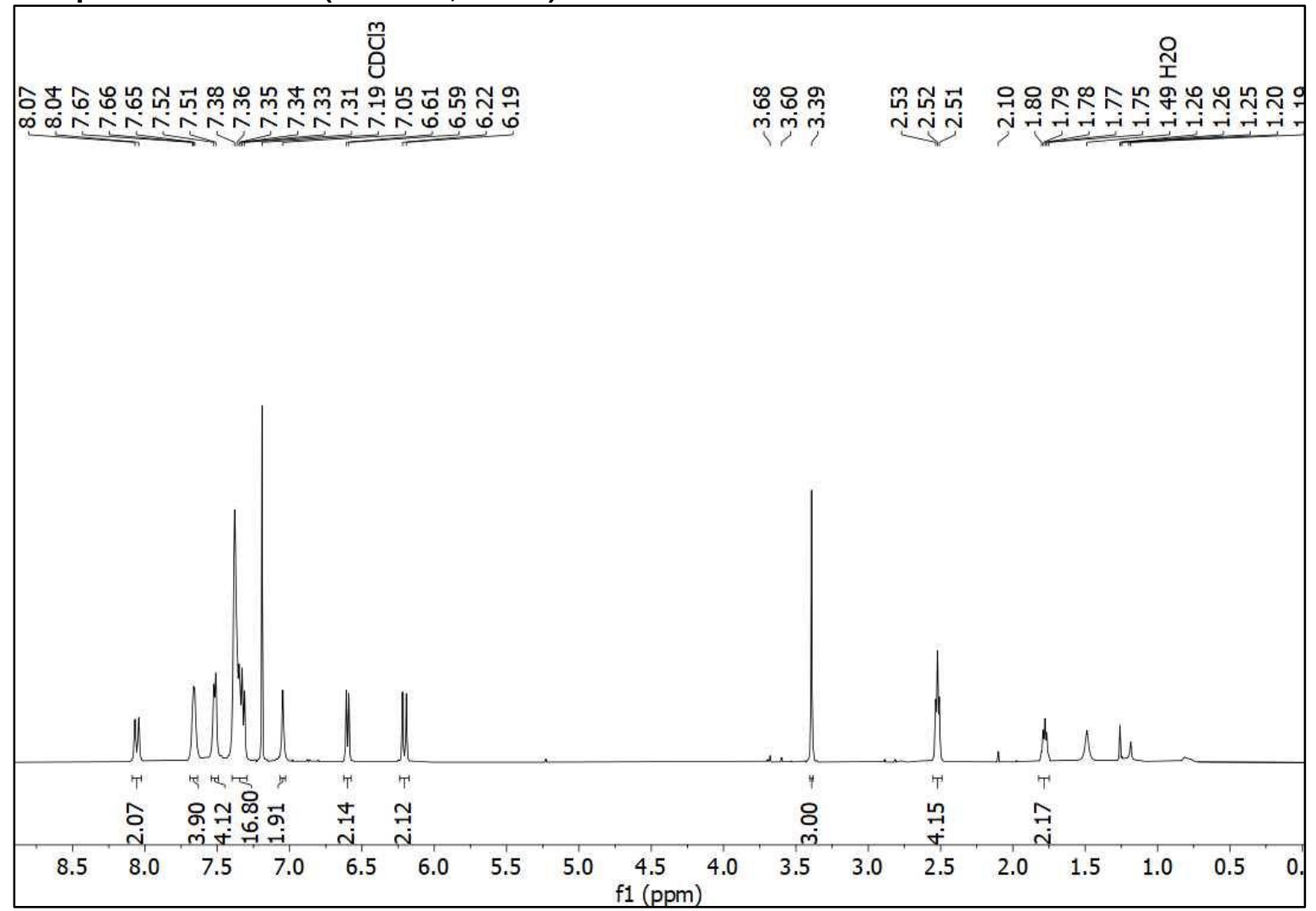

Compound 9: ${ }^{13} \mathrm{C}$ NMR (125 MHz, $\mathrm{CDCl}_{3}$ )

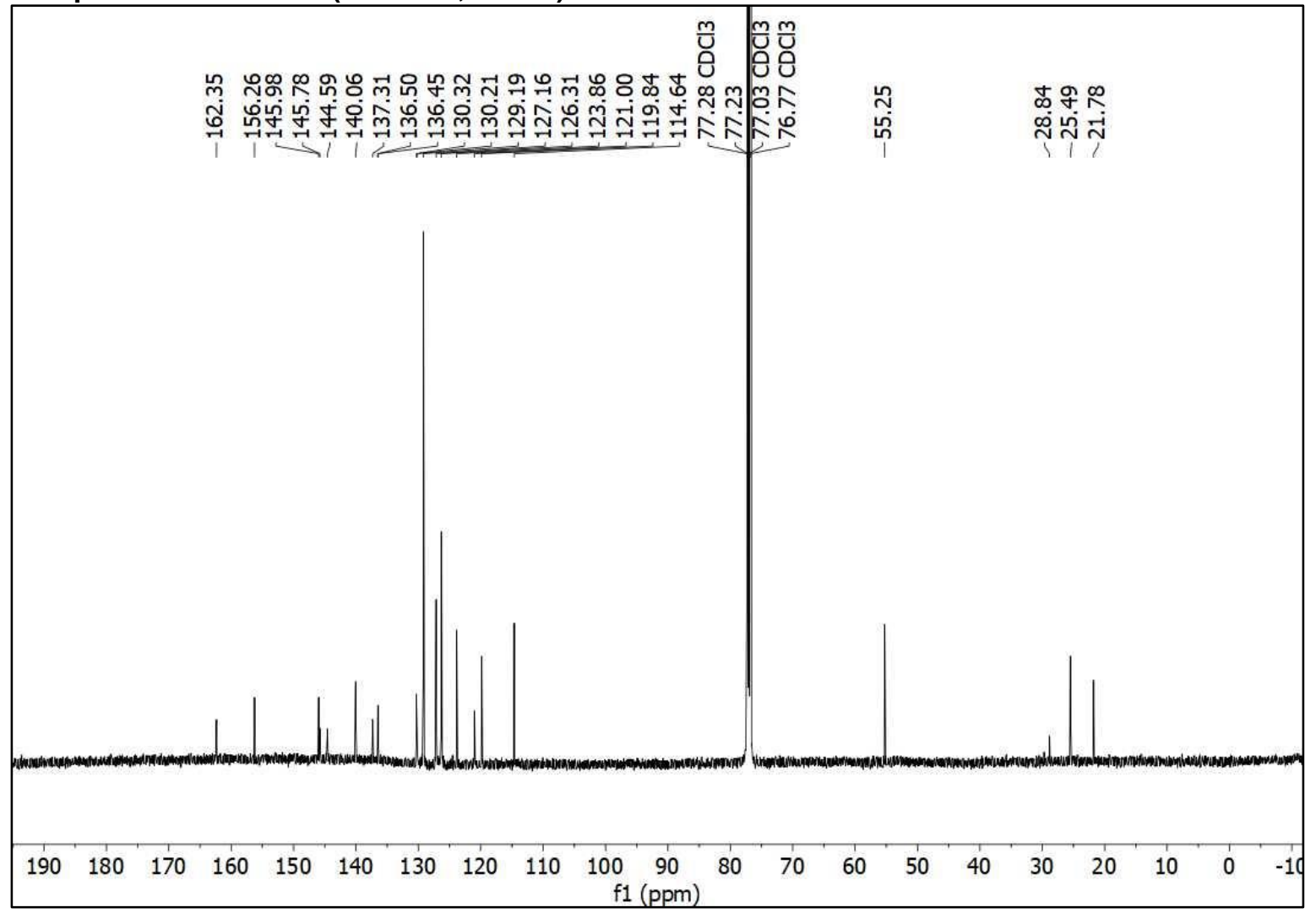


Compound 10: ${ }^{1} \mathrm{H}$ NMR (500 MHz, $\left.\mathrm{CD}_{3} \mathrm{OD} / \mathrm{CDCl}_{3}\right)$

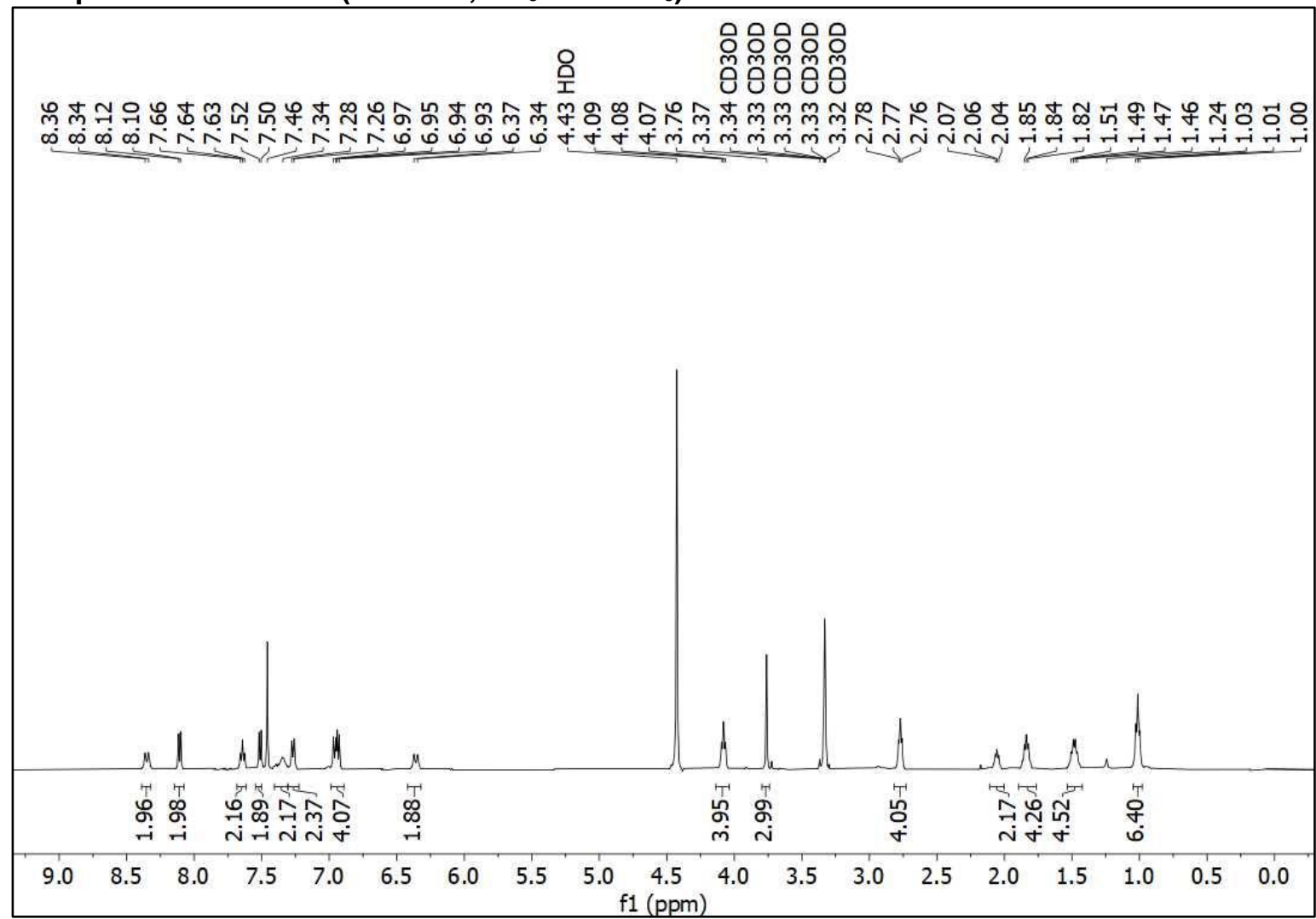

Compound 10: ${ }^{13} \mathrm{C}$ NMR (125 MHz, $\left.\mathrm{CD}_{3} \mathrm{OD} / \mathrm{CDCl}_{3}\right)$

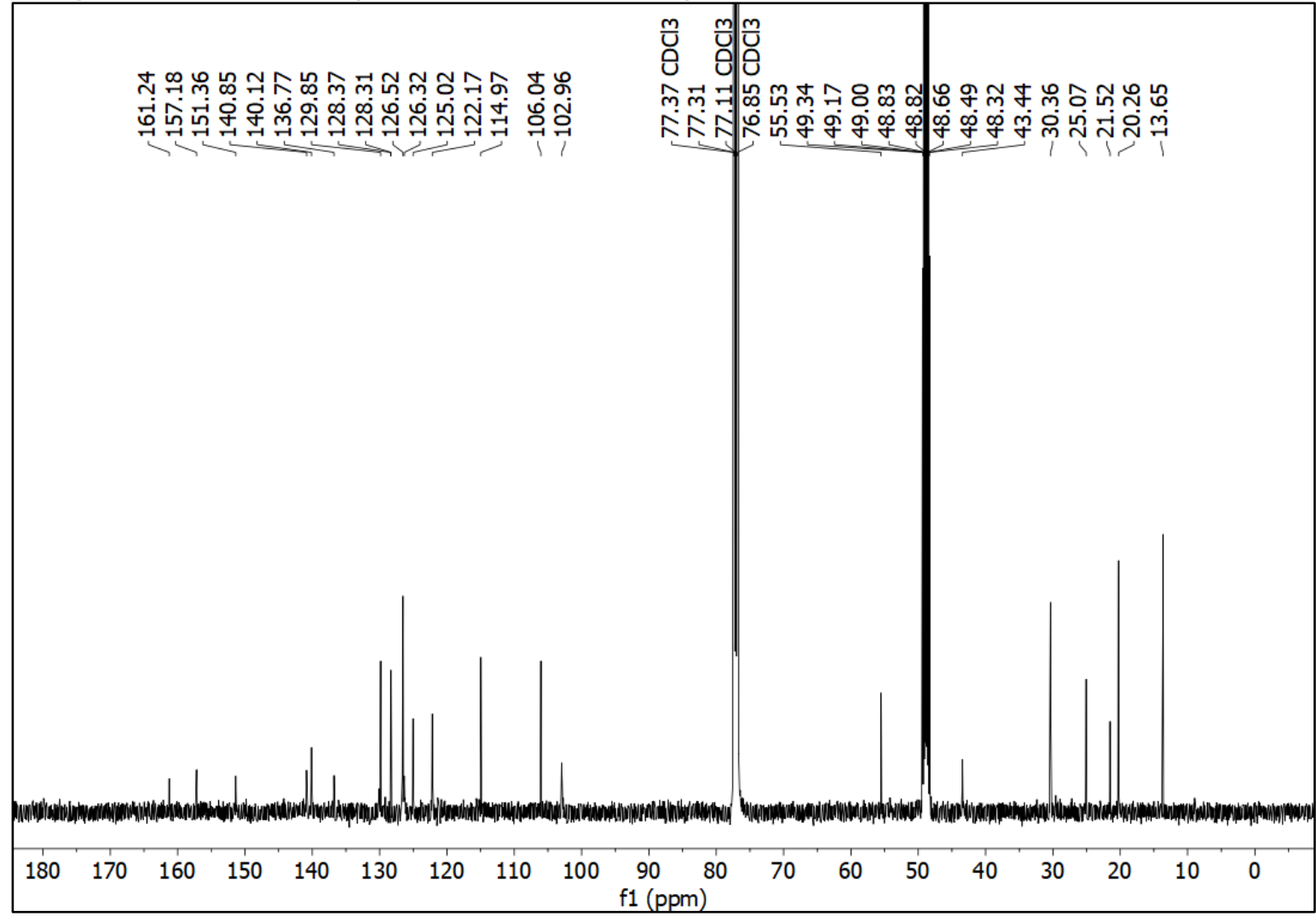


Compound 11: ${ }^{1} \mathrm{H}$ NMR (500 MHz, DMSO-d $\mathrm{d}_{6}$ )

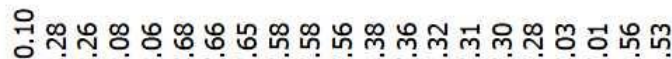

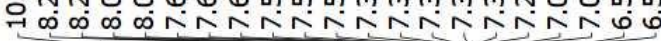

$$
\text { กิ } \sum_{\text {บิ }}^{\text {บิ }}
$$

ㅇำำ ฉ

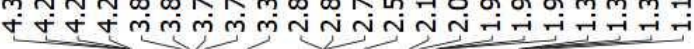

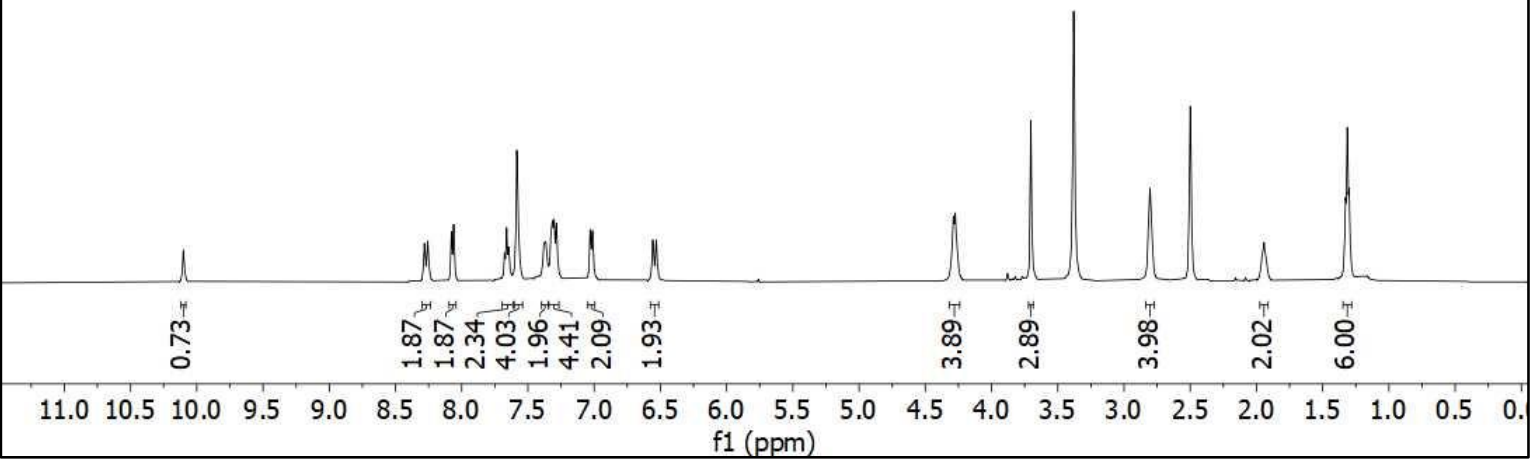

Compound 11: ${ }^{13} \mathrm{C}$ NMR (125 MHz, DMSO-d $\mathrm{d}_{6}$ )

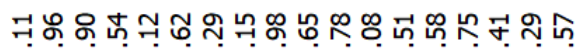

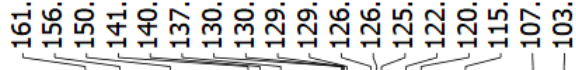

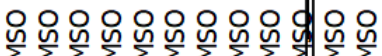

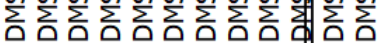

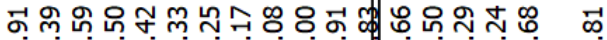

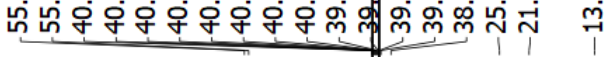


$\begin{array}{lllllllllllllllllll}30 & 170 & 160 & 150 & 140 & 130 & 120 & 110 & 100 & 90 & 80 & 70 & 60 & 50 & 40 & 30 & 20 & 10 & 0\end{array}$


Compound 12: ${ }^{1} \mathrm{H}$ NMR (500 MHz, $\mathrm{CDCl}_{3}$ )






\section{Supplementary References}

1. Schindelin, J. et al. Nat. Methods. 2012, 9, 676-682

2. W. Q. Feng, Y. Y. Zhang, Z. Li, S. Y. Zhai, W. J. Lv and Z. H. Liu, Anal. Chem., 2019, 91, 1575715762.

3. E. D. Cosco, A. L. Spearman, S. Ramakrishnan, J. G. P. Lingg, M. Saccomano, M. Pengshung, B. A. Arus, K. C. Y. Wong, S. Glasl, V. Ntziachristos, M. Warmer, R. R. McLaughlin, O. T. Bruns and E. M. Sletten, Nat. Chem., 2020, 12, 1123-1130.

4. Hansch, C.; Leo, A.; Taft, W. Chem. Rev. 1991, 91, 165-195.

5. R. M. U. Anal. Biochem. 2006, 354, 165-168. 